\title{
Metallothionein III Is Expressed in Neurons That Sequester Zinc in Synaptic Vesicles
}

\author{
Brian A. Masters, ${ }^{1, a}$ Carol J. Quaife, ${ }^{2}$ Jay C. Erickson, ${ }^{2}$ Edward J. Kelly, ${ }^{2}$ Glenda J. Froelick, ${ }^{2}$ Brian P. \\ Zambrowicz, ${ }^{2, b}$ Ralph L. Brinster, ${ }^{1}$ and Richard D. Palmiter ${ }^{2}$ \\ 'Laboratory of Reproductive Physiology, School of Veterinary Medicine, University of Pennsylvania, Philadelphia, \\ Pennsylvania 19104, and 2Howard Hughes Medical Institute and Department of Biochemistry, University of Washington, \\ Seattle, Washington 98195
}

\begin{abstract}
MT-III, a brain-specific member of the metallothionein gene family, binds zinc and may facilitate the storage of zinc in neurons. The distribution of MT-III mRNA within the adult brain was determined by solution and in situ hybridization and compared to that of MT-I mRNA. MT-III mRNA is particularly abundant within the cerebral cortex, hippocampus, amygdala, and nuclei at base of the cerebellum. Transgenic mice generated using $11.5 \mathrm{~kb}$ of the mouse MT-III $5^{\prime}$ flanking region fused to the $E$. coli lacZ gene express $\beta$-galactosidase in many of the same regions identified by in situ hybridization. MT-III mRNA was present in readily identifiable neurons within the olfactory bulb, hippocampus, and cerebellum, and $\beta$-galactosidase activity was localized to neurons throughout the brain, but not to glla, as determined by costaining with $X$-Gal and neural- and glia-specific antibodies. There is marked correspondence between the neurons that are rich in MT-III mRNA and those neurons that store zinc in their terminal vesicles. MT-III is found complexed with zinc in vivo and its expression in cultured cells leads to the intracellular accumulation of zinc and enhanced histochemical detection of zinc. These results are discussed in light of the possibility that MT-III may participate in the utilization of zinc as a neuromodulator.
\end{abstract}

[Key words: metallothionein, zinc-containing neurons, brain, transgenic mice, Timm's stain, in situ hybridization]

Metallothioneins (MT) are small, cysteine-rich, metal-binding proteins that are expressed in all eukaryotes that have been examined (Kägi and Kojima, 1987). In mammals, two isoforms, MT-I and MT-II, are expressed in most organs and they are regulated coordinately by a variety of metals, hormones, and xenobiotics (Hamer, 1986; Palmiter, 1987). Recent studies have revealed additional isoforms: a brain-specific isoform, MT-III

Received Feb. 16, 1994; revised Apr. 7, 1994; accepted Apr. 21, 1994.

We are grateful to Dr. Christopher J. Frederickson for his helpful comments and critical evaluation of this manuscript, Dr. John Silber for providing us with human astrocyte cell lines, Drs. Gary Hoyle and Eric Sandgren for their helpful advicc, and Mary Avarbock and Kathy Clegg for their technical assistance. This work was supported by National Institutes of Health grants HD-09172 (to R.D.P.) and HD-23657 (to R.L.B.).

Correspondence should be addressed to R. D. Palmiter, HHMI, SI -15, University of Washington, Seattle, WA 98195 .

aPresent address: Department of Physiology and Biophysics, University of Miami School of Medicine, P.O. Box 016430, Miami, FL 33101.

'Present address: Fred Hutchinson Cancer Research Center, Seattle, WA 98104. Copyright (c) 1994 Society for Neuroscience $0270-6474 / 94 / 145844-14 \$ 05.00 / 0$
(Uchida et al., 1991; Palmiter et al., 1992), and MT-IV, an isoform that is restricted to keratinizing epithelia (Quaife et al., 1994). MTs have been postulated to protect against metal toxicity (Webb, 1979; Beach and Palmiter, 1981; Durnam and Palmiter, 1987; Masters et al., 1994) and oxygen radicals (Thornalley and Vasak, 1985; Basu and Lazo, 1990; Hart et al., 1990; Tamai et al., 1993), regulate metal homeostasis, and participate in the biosynthesis of metalloproteins (Bremner, 1991; Suzuki et al., 1993).

The presence and distribution of MT-I and MT-II in the brain have been examined by in situ hybridization, radioimmunoassay, and immunocytochemistry. In addition, the regulation of MTs by metals and hormones has been examined in the brain and in neuronal or glial cell cultures. These studies indicate that MT-I and MT-II are expressed widely in the brain, primarily in ependymal and glial cells (Itano et al., 1991; Young et al., 1991; Nishimura et al., 1992). MT expression in the brain is relatively unperturbed by systemic administration of zinc or cadmium at dosages that strongly induce expression in the periphery (Itano et al., 1991; Nishimura et. al., 1992; Choudhuri et al., 1993). However, induction of MT-I and MT-II by metals can be readily demonstrated in cultured brain cells (Ebadi, 1991; Hidalgo et al., 1994), suggesting that metal accessibility limits MT gene responsiveness in vivo.

MT-III was discovered by virtue of its ability to inhibit the survival of neonatal rat cortical neurons in vitro (Uchida et al., 1991). The human and mouse forms of MT-III are similar to MT-I and MT-II except for the insertion of a threonine residue after the fifth amino acid and the insertion of a six amino acid block near the C-terminus (Uchida ct al., 1991; Palmiter et al., 1992). Although the biophysical nature of MT-III has not been examined in detail, it appears to coordinate zinc, copper, and cadmium with the same stoichiometry and affinity as the other MTs (D. Winge, personal communication). Thus, there is no evidence that these extra amino acids influence its metal-binding properties. However, it is possible that these unique structural features allow MT-III to interact specifically with other molecules. Indeed, the inhibition of cortical neuron survival is specific to the MT-III isoform of MT (Uchida et al., 1991; Erickson et al., 1994), although the mechanism of this inhibition and its physiological significance are unclear. Using polyclonal antisera generated against a unique peptide derived from human MTIII, Uchida et al. (1991) reported that MT-III protein is present exclusively in glial cells and that it is greatly depleted in cortical regions of individuals manifesting Alzheimer's disease (AD). 
The existence of a brain-specific isoform of MT-III suggests that it might have important neurophysiological functions. This idea is reinforced by its potential involvement in AD. As a first step in elucidating its functions in the brain, we cloned the murine M'I-III gene (Palmiter et al., 1992), which provides a means for the localization and quantitation of its mRNA and will facilitatc analyses of its function. There is considcrable cvidence that zinc is a neuromodulator with effects on subtypes of glutamate and GABA receptors (see Discussion). We show here that murine MT-III is localized predominantly in neurons that sequester zinc in synaptic vesicles (Slomianka, 1992), which leads to us to propose that it may play a special role in the utilization of zinc as a neuromodulator.

\section{Materials and Methods}

Determination of MT $m R N A$ levels in mouse. Various tissues from B6/ SJL F1 hybrid mice were isolated from animals sacrificed by lethal $\mathrm{CO}_{2}$ asphyxiation, and quick frozen in liquid $\mathrm{N}_{2}$. Frozen tissues were digested in $1 \times$ SET [ $10 \mathrm{~m}$ Tris, $5 \mathrm{~mm}$ EDTA, $1 \%$ SDS (SET buffer) containing $100 \mu \mathrm{g} / \mathrm{ml}$ proteinase $\mathrm{K}$ (Boehringer-Mannheim, Indianapolis, IN)] at $42^{\circ} \mathrm{C}$ for $1.5 \mathrm{hr}$, and then extracted with phenol-chloroform. Total nucleic acids were precipitated with ethanol and then dissolved in $0.2 \times$ SET, and aliquots (up to $50 \mu \mathrm{g}$ ) were hybridized overnight at $45^{\circ} \mathrm{C}$ with about $10,000 \mathrm{cpm}$ of probe in $40 \mu \mathrm{l}$ containing $0.6 \mathrm{M} \mathrm{NaCl}$ and $10 \%$ formamide. Oligonucleotide probes complementary to the 3 '-untranslated region of MT-I mRNA (\#57 5' GGGACAAATGATTTGGGGGCAAAAG $3^{\prime}$ ) and a unique region of MT-III coding region (\#350 $5^{\prime}$

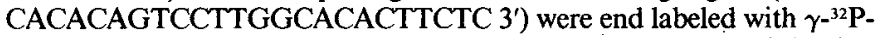
ATP using T4 polynucleotide kinase, and gel purified. The hybridization mixture was diluted to $1 \mathrm{ml}$ with $\mathrm{S}_{1}$ buffer containing $15 \mathrm{U}$ of $\mathrm{S}_{1}$ nuclease and $100 \mu \mathrm{g}$ of carrier DNA and incubated for $1 \mathrm{hr}$ at $45^{\circ} \mathrm{C}$. The $\mathrm{S}_{1}$ resistant probe was precipitated by adding trichloroacetic acid to $0.6 \mathrm{M}$; the precipitate was collected on Whatman GF/C filters and counted in a Packard scintillation counter. Standards with known amounts of MT-I or MT-III mRNA were used to calculate the amount of mRNA in cach sample. DNA content, as measured by fluorescence of bisbenzidine $\mathrm{H} 33258$, was used to determine the number of cells in each sample, assuming $6.4 \mu \mathrm{g}$ of DNA per diploid cell.

In situ hybridization. In situ hybridization and autoradiography were performed essentially as described by Mark et al. (1992). C57BL/6 mice were sacrificed by ether $/ \mathrm{CO}_{2}$ asphyxiation. The brains were immediately removed, placed in OCT compound (Miles Scientific, Stamford, CT), frozen on dry ice, and stored at $-70^{\circ} \mathrm{C}$ until sectioning. Sections $(10$ $\mu \mathrm{m})$ were cut, placed on RNase-free glass microscope slides that had been dipped in 2\% 3-aminopropyltriethoxysilane (Sigma, St. Louis, MO) in acetone followed by three rinses in $\mathrm{H}_{2} \mathrm{O}$, and air dried for 15-30 min. The sections were stored at $-70^{\circ} \mathrm{C}$ until used for analysis.

Slides prepared as above were equilibrated at room temperature, placed in $4 \%$ paraformaldehyde in $4^{\circ} \mathrm{C}$ phosphate-buffered saline (PBS; 140 $\mathrm{mM} \mathrm{NaCl}, 2 \mathrm{~mm} \mathrm{KCl}, 1.5 \mathrm{~mm} \mathrm{Na} \mathrm{PO}_{4}, 1.5 \mathrm{mM} \mathrm{KH}_{2} \mathrm{PO}_{4}$ ) for $5 \mathrm{~min}$, and rinsed three times in PBS ( $5 \mathrm{~min}$ each). To lessen background signal the sections were treated with $0.25 \%$ acetic anhydride in $0.1 \mathrm{~m}$ triethanolamine buffer ( $\mathrm{pH} \mathrm{9.5),} \mathrm{followed} \mathrm{by} \mathrm{incubation} \mathrm{in} 0.2 \mathrm{M}$ Tris ( $\mathrm{pH} \mathrm{7.5),}$ $0.1 \mathrm{~m}$ glycine for $10 \mathrm{~min}$. After a PBS rinse, the sections were dehydrated by passing them through a graded ethanol series followed by soaking in chloroform for $5 \mathrm{~min}$ to delipidate the sections. The sections were then rehydrated through the graded ethanol series. After a rinse in PBS and removal of excess fluid (but not to dryness) the slides were incubated in a prehybridization mix [50\% formamide, $1 \times$ Denhardt's solution, $10 \%$ polyethylene glycol $6000,200 \mathrm{~mm}$ dithiothreitol (DTT), $1.0 \mathrm{mg} /$ ml yeast RNA, $200 \mathrm{ng} / \mathrm{ml}$ denatured herring sperm DNA, $0.6 \mathrm{M} \mathrm{NaCl}$, $10 \mathrm{~mm} \mathrm{NaOAc}, 1 \% \mathrm{SDS}, 5 \mathrm{mg} / \mathrm{ml}$ heparin] for $30-60 \mathrm{~min}$ at $60^{\circ} \mathrm{C}$.

For the production of riboprobes, $12 \mu \mathrm{l}$ of ${ }^{35} \mathrm{~S}-\mathrm{UTP}(150 \mu \mathrm{Ci}$; Amersham, Arlington Heights, IL) was dried down and resuspended in 3.5 $\mu \mathrm{l}$ of reaction mix [7.5 $\mu \mathrm{l}$ of $\mathrm{H}_{2} \mathrm{O}, 1.25 \mu$ l of $0.2 \mathrm{M}$ DTT, $3.75 \mathrm{~mm}$ each ATP, CTP, GTP; $1.5 \mu 1$ (30 U) of RNAguard (Pharmacia, Piscataway, $\mathrm{NJ}$ ), and $5 \mu \mathrm{l}$ of $5 \times$ transcription buffer (Promega, Madison, WI)]. Template was then added $(1 \mu \mathrm{l}, 500 \mathrm{ng} / \mu \mathrm{l})$ along with the appropriate RNA polymerase (10 U of $\mathrm{T} 3$ of $\mathrm{T} 7 \mathrm{in}$ a volume of $0.5 \mu \mathrm{l})$ and the mixture was incubated for $1 \mathrm{hr}$ at $37^{\circ} \mathrm{C}$. The transcription reaction was diluted to $40 \mu \mathrm{l}$ with $\mathrm{dH}_{2} \mathrm{O}$ and DNA was removed by incubating at $37^{\circ} \mathrm{C}$ for $50 \mathrm{~min}$ after the addition of $5 \mu \mathrm{l}$ of $10 \times$ DNase I buffer $[0.5$ м Tris (pH 7.5), $0.1 \mathrm{M} \mathrm{MgCl}_{2}, 500 \mu \mathrm{g} / \mathrm{ml} \mathrm{BSA],} 2.5 \mu \mathrm{l}$ of $0.2 \mathrm{M}$ DTT, $5 \mu \mathrm{l}(5 \mathrm{U})$ of RNase-free DNase I (Boehringer-Mannheim, Indianapolis, IN), and $2 \mu \mathrm{l}(40 \mathrm{U})$ of RNAguard. Following the DNase I treatment, the reaction mixtures were extracted with phenol/ $\mathrm{CHCl}_{3}$, followed by a $\mathrm{CHCl}_{3}$ extraction, and ethanol $(95 \%)$ precipitation. The probe was dissolved in $10 \mu \mathrm{l}$ of $10 \mathrm{~mm}$ Tris (pH 8.0), $1.0 \mathrm{~mm}$ EDTA. Sixteen microliters of hybridization mix (prehybridization mixture with probe), with a probe concentration of $0.2-0.3 \mu \mathrm{g} / \mathrm{ml} / \mathrm{kb}$ probe length, were added to each slide, coverslips applied, and sealed with a 1:1 mixture of petroleum ether and rubber cement. The sections were hybridized for approximately $16 \mathrm{hr}$ at $60^{\circ} \mathrm{C}$. The coverslips were removed and sections were rinsed in $4 \times$ SSC buffer $(20 \times$ SSC: $3 \mathrm{M} \mathrm{NaCl}, 0.3 \mathrm{~m}$ trisodium citrate) containing $10 \mathrm{~mm}$ DTT. Unhybridized ribroprobe was digested by incubating slides in a buffer containing $0.5 \mathrm{M} \mathrm{NaCl}, 10 \mathrm{~mm}$ Tris (pH $8.0), 10 \mathrm{~mm}$ DTT and RNase A $(20 \mathrm{mg} / \mathrm{ml})$ for $30 \mathrm{~min}$ at $37^{\circ} \mathrm{C}$. This was followed by a series of high stringency washes: $2 \times$ SSC, $50 \%$ formamide, $10 \mathrm{mM}$ DTT at $60^{\circ} \mathrm{C}$ for $30 \mathrm{~min} ; 1 \times \mathrm{SSC}, 50 \%$ formamide, $10 \mathrm{~mm}$ DTT at $60^{\circ} \mathrm{C}$ for $30 \mathrm{~min} ; 0.1 \times \mathrm{SSC}$ at $37^{\circ} \mathrm{C}$ for $30 \mathrm{~min}$. The sections were air dried and coated with emulsion (NTB-2, Eastman Kodak Co., Rochester, NY) for autoradiography. Coated slides were incubated at $4^{\circ} \mathrm{C}$, in the dark, for varying times (2-6 weeks). A Nikon Microphot FX research microscope was used for analysis and photography.

To determine that the in situ hybridization conditions would not allow cross-hybridization to nonspecific MTs, each of the probes was hybridized to duplicate Northern blots loaded with recombinant MT-I or MT-III mRNA made in transfected BHK cells. When these blots were hybridized and washed under the conditions used for the in situ hybridization, namely, hybridization in $50 \%$ formamide at $45^{\circ} \mathrm{C}$ and a wash in $1 \times \mathrm{SSC}$ at $60^{\circ} \mathrm{C}$ in $50 \%$ formamide, the probes hybridized only to their respective mRNAs.

Construction of $m M T-I I I-n l a c Z$ plasmid and transgenic mice. The mMT-III-nlac $Z$ construct was prepared by fusing approximately 11.5 $\mathrm{kb}$ of DNA upstream of the initiation codon of the mMT-III gene to the $\mathrm{n} l a c Z$ construct prepared by Jacques Peschon and described by Mercer et al. (1991). The $n l a c Z$ construct contains the nuclear localization signal derived from SV-40 T-antigen at the N-terminus of the $E$. coli lacZ gene. The mMT-III 5 -sequence was added in two steps. First, the DNA between +7 and +383 of mMT-III (Palmiter et al., 1992) was amplified by PCR and inserted into the polylinker of nlacZ; this sequence includes a unique KasI restriction site and the upstream polylinker has a NotI site. Then an $11.4 \mathrm{~kb}$ NotI-KasI fragment from a genomic mMT-III clone was inserted into this vector. A $15 \mathrm{~kb}$ NotINruI fragment that includes the entire MT-III-nlacZ construct was isolated from the plasmid vector by agarose gel electrophoresis, electroeluted into a dialysis bag, phenol/chloroform extracted, and precipitated with ethanol. The resulting DNA was dissolved in $10 \mathrm{~mm}$ Tris$\mathrm{HCl}, 0.25 \mathrm{~mm}$ EDTA, pH 7.5; the DNA concentration was determined by fluorescence of bisbenzimide $\mathrm{H} 33258$, and then diluted to $2 \mathrm{ng} / \mu \mathrm{l}$ for microinjection into pronuclei of B6/SJL fertilized mouse eggs (Brinster et al., 1985). Transgenic mice were identified by dot hybridization of tail DNA (Palmiter et al., 1982; Brinster et al., 1985). Injection of the mMT-III-nlac $Z$ construct into fertilized one-cell embryos and subsequent screening resulted in the identification of seven founder animals. Brains from offspring of each founder were examined using $X-G a l$ histochemistry to determine expression of the transgene. ILAR designations for transgenic lines that were established for this study are 4708-2 [TgN(MT3nlacZ)221 Bri], 4708-5 [TgN(MT3nlacZ)207Bri], and 4708-8 [TgN(MT3nlacZ)222Bri].

$X$-Gal staining technique. Tissues for X-Gal histochemical staining were isolated into $4^{\circ} \mathrm{C}$ phosphate-buffered saline (PBS), and fixed in $4 \%$ paraformaldehyde/ $0.1 \mathrm{M} \mathrm{NaH}_{2} \mathrm{PO}_{4}\left(\mathrm{pH} \mathrm{7.4)}\right.$ for $1 \mathrm{hr}$ at $4^{\circ} \mathrm{C}$. Tissue fragments were then rinsed in three changes $0.1 \mathrm{M} \mathrm{NaH}_{2} \mathrm{PO}_{4}$ (pH 7.4) $2 \mathrm{mM} \mathrm{MgCl}_{2}, 0.01 \%$ sodium deoxycholate, and $0.02 \%$ NP-40 with 30 min for each rinse. Development of X-Gal product was initiated by incubating the tissue fragments for $12-24 \mathrm{hr}$ at $37^{\circ} \mathrm{C}$ in a staining buffer composed of the rinse buffer and $1 \mathrm{mg} / \mathrm{ml} \mathrm{X-Gal} \mathrm{(Gold} \mathrm{Scientific,} \mathrm{St.}$ Louis, MO), $5 \mathrm{mM} \mathrm{K}_{3} \mathrm{Fe}(\mathrm{CN})_{6}$, and $5 \mathrm{mM} \mathrm{K}_{4} \mathrm{Fe}(\mathrm{CN})_{6}(\mathrm{pH} \mathrm{7.3-7.6)}$ Fragments were postfixed $24-48 \mathrm{hr}$ in $10 \%$ formalin for complete fixation of large tissue pieces. Fixed tissues were equilibrated in PBS prior to embedding in OCT for cryostat sections, or dehydrated in an ethanol series and embedded paraffin for microtome sections.

Histochemistry and immunohistochemistry of brain sections. Animals were anesthetized with Avertin $(\beta$-tribromoethanol, $1 \mu \mathrm{g} / \mathrm{kg}$ body weight 
Aldrich Chemical Co., Milwaukee, WI), and perfused at $4^{\circ} \mathrm{C}$ with $5 \mathrm{ml}$ of $0.2 \%$ paraformaldehyde, $0.1 \mathrm{M} \mathrm{NaH}_{2} \mathrm{PO}_{4}$ at $25^{\circ} \mathrm{C}$, followed by $10 \mathrm{ml}$ of $0.2 \%$ paraformaldehyde, $0.1 \mathrm{M} \mathrm{NaH}_{2} \mathrm{PO}_{4}$. Brains were isolated in PBS at $4^{\circ} \mathrm{C}$ and fixed for an additional $50 \mathrm{~min}$ in $0.2 \%$ paraformaldehyde, $0.1 \mathrm{M} \mathrm{NaH}_{2} \mathrm{PO}_{4}$ at $4^{\circ} \mathrm{C}$. Tissues were rinsed and stained as described above for $\beta$-galactosidase histochemistry. Brains used for histochemical staining were fixed for an additional $48 \mathrm{hr}$ in $10 \%$ formalin. Brains used for immunocytochemical colocalization of $\beta$-gal with neural antigens were quick frozen in OCT compound and $12 \mu \mathrm{m}$ cryostat sections were mounted on $0.5 \%$ gelatin-coated slides. Sections were air dried and incubated in Tris-buffered saline (TBS; $150 \mathrm{~mm} \mathrm{NaCl}, 20 \mathrm{~mm}$ Tris- $\mathrm{HCl}$, $\mathrm{pH} 7.2$ ), 2\% normal fetal calf serum (FCS) for $5 \mathrm{~min}$. All procedures below were performed at room temperature unless indicated. Slides were transferred to $84 \%$ methanol, $6 \% \mathrm{H}_{2} \mathrm{O}_{2}$ and incubated for $30 \mathrm{~min}$ to inhibit endogenous peroxidase activity. To inhibit nonspecific immunoreactivity slides were first incubated with avidin and biotin blocking solutions (Vector Research, Burlingame, CA) supplemented to $2 \%$ FCS for $15 \mathrm{~min}$ cach, separated by a single $5 \mathrm{~min}$ wash with TBS, $2 \%$ FCS. This was followed by a blocking solution containing TBS, $2 \%$ FCS, $30 \%$ normal goat serum for $30 \mathrm{~min}$. Slides were rinsed in three washes of TBS, 2\% FCS and then incubated with rabbit anti-GFAP (diluted 1:70; Sigma), S-100 IgG (diluted 1:65; Sigma), or mouse anti-MAP-5 ascites (diluted 1:50; Sigma) in TBS, $2 \%$ FCS for $1 \mathrm{hr}$ or $12 \mathrm{hr}$ at $4^{\circ} \mathrm{C}$. Following incubation with primary antibodies, slides were rinsed three times in 0.1 м TBS. For rabbit-generated primary antibodies, slides were then incubated in a solution containing swine anti-rabbit IgG secondary antibody (diluted 1:10; Universal Rabbit Kit, DAKO Corp., Carpinteria, CA), washed as above, and incubated in peroxidase-antiperoxidase immune complex (undiluted from kit). Slides incubated with the mouse anti-MAP-5 antibody were incubated in biotinylated goat anti-mouse IgG (diluted 1:15; Biogenics Inc.), for $30 \mathrm{~min}$. Slides were rinsed three times in TBS and then incubated with horseradish peroxidase-linked streptavidin. Slides were rinsed three times in $0.1 \mathrm{M}$ TBS for $5 \mathrm{~min}$ each rinse, and then exposed to $0.5 \mathrm{mg} / \mathrm{ml}$ diaminobenzidine, $0.02 \% \mathrm{H}_{2} \mathrm{O}_{2}$ for 5 min at $37^{\circ} \mathrm{C}$ to develop peroxidase activity.

Cell culture. Neonatal $(<24 \mathrm{hr}$ old $)$ mice were decapitated and brains isolated into buffered-saline under aseptic conditions. Neocortex was dissected from surrounding tissue in Dulbecco's Modified Eagle's Medium (DMEM; Life Technologies, Gaithersburg, MD) supplemented with $20 \%$ FCS. For glial cultures, the tissue was minced and vortexed in a $15 \mathrm{ml}$ centrifuge tube in DMEM, 20\% FCS at maximum speed for $1 \mathrm{~min}$. The resulting cell suspension was filtered through $60 \mu \mathrm{m}$ Nitex nylon mesh (Tetko Inc., F.lmsford, NY) and approximately $10^{6}$ cells were plated onto $10 \mathrm{~cm}$ dishes. These cells were cultured for 7-10 d in DMEM, 20\% FCS in a $5 \% \mathrm{CO}_{2}, 95 \%$ air, $98 \%$ humidity atmosphere at $37^{\circ} \mathrm{C}$. For neuron cultures, brains were minced and treated with $0.1 \%$ trypsin at $37^{\circ} \mathrm{C}$ for $15 \mathrm{~min}$, diluted $1: 1$ with DMEM, 10\% FCS, and centrifuged at $1000 \mathrm{rpm}$ for $5 \mathrm{~min}$. The pellet was resuspended in DMEM, 10\% FCS and was filtered through $60 \mu \mathrm{m}$ nylon mesh, and the cells were plated onto astrocyte feeder layers at approximately $1.5 \times$ $10^{5} \mathrm{cells} / \mathrm{cm}^{2}$. These cultures were maintained 1 week under the same conditions as glia cultures. Human astrocytoma lines UW18, WW457, CRL1690, SNB19, and HTB16 were grown and screened for MT-III mRNA as above.

Expression of $M T-I I I$ in a mammalian cell line. A $1.3 \mathrm{~kb}$ SnaBINacI fragment that includes all the coding exons of the mMT-III gene was cloned into the pNUT vector (Palmiter et al., 1987) such that MTIII expression would be under the control of the mMT-I promoter. This vector also carries a dihydrofolate reductase selectable gene. The resulting plasmid was transfected into baby hamster kidney (BHK) cells by the calcium phosphate method and cells resistant to $200 \mu \mathrm{M}$ methotrexate were selected. This population expressed approximately 1200 molecules of MT-III mRNA per cell and was 10 -fold more resistant to cadmium exposure than the parental cell line. A subpopulation that survived selection in $25 \mu \mathrm{M} \mathrm{CdSO}{ }_{4}$ was used for these studies. BHK cells were grown in DMEM with $10 \%$ fetal calf serum; this medium contains about $4 \mu \mathrm{M}$ zinc and $0.3 \mu \mathrm{M}$ copper as measured by ICP.

Detection of zinc by Timm's stain. C57BL/6 female mice were sacrificed by a lethal injection of Avertin and histochemical demonstration of heavy metals was performed as described by Danscher (1981). Briefly, the brachial artery was severed, and animals were cardiac perfused with $0.1 \%$ sodium sulfide in $86 \mathrm{~mm}$ phosphate buffer ( $\mathrm{pH} 7.2$ ) for $5 \mathrm{~min}$ followed by neutral buffered formalin (NBF; $10 \%$ formalin, $32 \mathrm{~mm}$ $\mathrm{NaH}_{2} \mathrm{PO}_{4}, 50 \mathrm{mM} \mathrm{Na} \mathrm{HPO}_{4}$ ) for $5 \mathrm{~min}$. Brains were removed and placed in NBF for $5 \mathrm{hr}$. Brains were embedded in OCT compound and $30 \mu \mathrm{m}$ sections were cut. Visualization of sulfide-precipitated metals within brain sections was accomplished by development with $0.1 \%$ silver lactate and $0.85 \%$ hydroquinone dissolved in $30 \%$ citrate-buffered arabic gum for $60 \mathrm{~min}$ at room temperature. Timm's stain was also performed on BIIK cells cultured on glass microscope slides. The slides were placed in racks, rinsed three times for $30 \mathrm{sec}$ each in cold PBS, and then dipped in $0.3 \%$ sulfide in $86 \mathrm{~mm}$ Tris- $\mathrm{HCl}(\mathrm{pH} \mathrm{7.2)}$ for $3 \mathrm{~min}$. Slides were then rinsed three more times in PBS and placed in NBF prior to visualization of histochemically reactive metal as described above.

Metal analysis. BHK cultures were rinsed three times with PBS, scraped into $0.2 \times$ SET, sonicated briefly, and DNA concentration determined by fluorimetry. The disrupted cell suspension was digested in nitric acid (Ultrex, J. T. Baker, Inc., Phillipsburg, NJ), evaporated to dryness, and resuspended in $2.5 \%$ nitric acid; metal content was determined by inductively coupled plasma emission spectroscopy (ICP) using a JarrelAsh 955 spectrophotometry (Fassel, 1978). The nitric acid was analyzed to determine the background metal concentrations, and was subtracted from experimental values. Data were standardized for cell number.

\section{Results}

\section{Expression of MT mRNAs in brain}

To measure the accumulation of MT-III and MT-I mRNA during development, oligonucleotide probes specific for either MTIII or MT-I were hybridized with total nucleic acids isolated from the brains of fetal mice starting at day 16.5 postcoitus and extending through postnatal day 24 and the adult. Standards with known amounts of these mRNAs were prepared that allowed the determination of the absolute amount of each of these mRNAs (see Materials and Methods). Figure $1 A$ shows that MT-III mRNA is present in the brain at embryonic day 16.5 and increases about eightfold to reach adult levels at day 13 after birth. MT-III mRNA is detectable in embryonic heads at day 13.5, the earliest time point examined, but not in embryonic bodies. At day 16.5, MT-III mRNA is enriched in the brain relative to the entire head, consistent with it exhibiting brainspecific expression, although there is a small amount in the body that included the spinal cord. For comparison, the accumulation of MT-I mRNA was also measured in the same samples. Although the mRNA accumulation curves for these MTs are different, the amounts of MT-I transcripts in the embryonic heads and adult brains are only slightly less than those of MT-III at these ages (Fig. $1 B$ ). At embryonic day 16.5, MT-I mRNA is more abundant in heads than in isolated brains of similar age but it is most abundant in the body, in contrast to MT-III mRNA.

We showed previously that mouse MT-III mRNA is expressed predominantly in the brain of adult mice (Palmiter et al., 1992). To examine its distribution, various regions of the brain were dissected and MT-III and MT-I mRNA concentrations were determined. Transcripts for both MT-III and MT-I were detected in all areas of the brain examined as well as in the spinal cord. Both mRNAs were expressed at approximately equal levels in all regions with the exception of the hippocampus, which was enriched with MT-III mRNA (Fig. 2).

\section{Localization of MT-III mRNA in neurons}

To obtain a more precise localization of MT expression in the adult brain, in situ hybridization was performed using either sense or antisense riboprobes derived from mouse cDNAs corresponding to MT-III and MT-I mRNAs. Hybridization and washing conditions were established that would prevent crosshybridization of these probes, which are $71 \%$ identical (see Materials and Methods). Sagittal and coronal sections were hybridized, washed, and exposed for several weeks prior to development. With the antisense MT-III probe, there was intense hybridization to neurons of the hippocampus in the CA1-CA3 

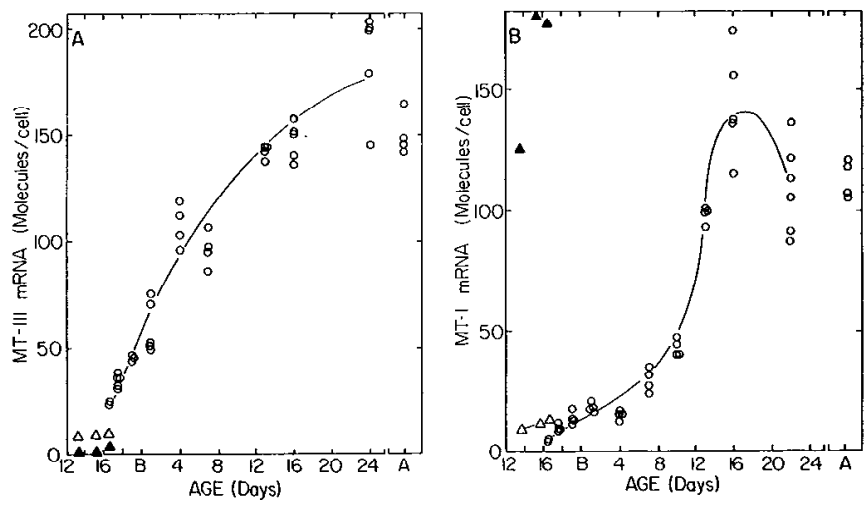

Figure 1. Abundance of MT-IIl and MT-I mRNA in brain during development. $A$, MT-III mRNA and $B$, MT-I mRNA were measured in total nucleic acids at various pre- and postnatal ages by solution hybridization. Specific hybridization is plotted as molecules per cell (see Materials and Methods) for brain (open circles), heads (open triangles), and bodies (solid triangles). Embryonic age, birth $(B)$, postnatal age, and adult $(A)$ are indicated on the abscissa.

regions as well as the dentate gyrus (Fig. $3 A$ ). Most of the grains were located over pyramidal neurons and granule cells with weak hybridization within the fiber-rich areas: the stratum oriens and stratum radiatum of the hippocampus, and the molecular layer of the dentate gyrus (Fig. $3 E$ ). There were also robust hybridization signals associated with large, easily identifiable neurons throughout the neocortex (Fig. $3 A$ ), particularly in the deeper layers of the cortex (Fig. 3G). Similar levels of hybridization were noted in lateral (Fig. 3A), interpositus and medial deep cerebellar nuclei, brainstem (Fig. $3 A$ ), the amygdala (Fig. 3G), and associated with the Purkinje cell layer in the cerebellar cortex (Fig. $3 H$ ). A lower level of hybridization was observed in many other areas (Fig. $3 A$ ), including several thalamic, hypothalamic, and mesencephalic nuclei. Hybridization to the cells lining the ventricles and epithelial cells of the choroid plexus was also prominent (Fig. $3 A$, and see below). The basal ganglia were relatively devoid of cells with which the MT-III probe hybridized (Fig. $3 A$ ). In addition, areas associated with white matter, such as the cingulum and fimbria, appeared to contain only infrequent sites of hybridization.

The MT-I antisense probe hybridizcd to many of the same regions as the MT-III probe (Fig. $3 B$ ); grains were most concentrated in the cerebellum, brainstem nuclei, and the choroid plexus. In the hippocampus, MT-I transcripts were primarily in the CA3 region and throughout fiber-rich regions (Fig. $3 F$ ). Sections hybridized with the MT-I antisense riboprobe exhibited a significant signal in areas of white matter, unlike that observed with the MT-III probe. There was an extremely weak signal produced with either the MT-III or MT-I sense probes (Fig. 3C,D).

\section{Expression of MT-III-nlacZ transgene}

To facilitate a more detailed analysis of the expression pattern of MT-III, we fused $11.5 \mathrm{~kb}$ of $5^{\prime}$ flanking region from the mMTIII gene to an $E$. coli lac $Z$ gene that encodes $\beta$-galactosidase ( $\beta$ gal) with a nuclear localization signal (Mercer et al., 1991). Seven lines of transgenic mice were produced and three lines that exhibited the strongest expression were studied in detail. Transgene expression was limited to the brain and spinal cord in adults and the expression pattern of $\beta$-gal (Fig. $4 A$ ) overlapped areas of endogenous MT-III gene expression. There was extensive

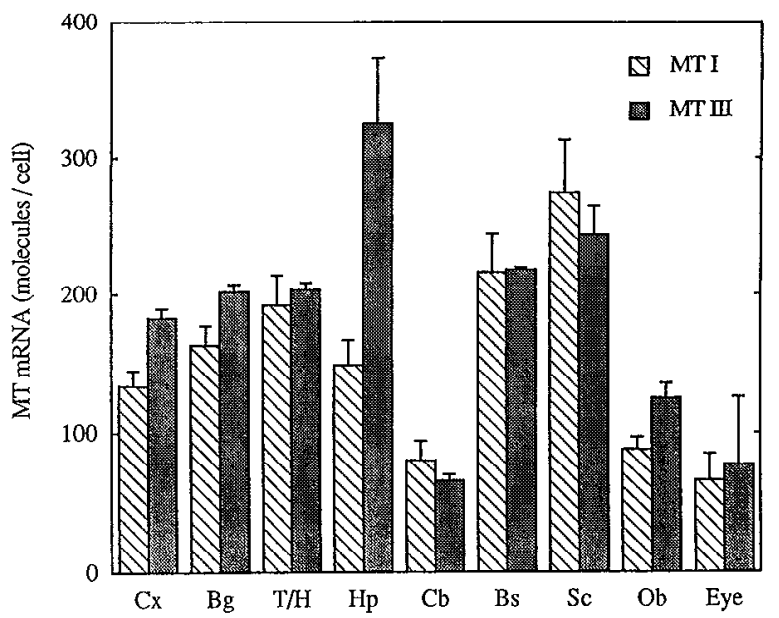

Figure 2. Regional expression of MT-III and MT-I mRNA in mouse brain. Various regions of the brain were dissected from adult mouse brain, total nucleic acids were prepared and hybridized with labeled oligonucleotides specific for MT-I ( hatched bars), and MT-III (solid bars) as in Figure 1; $C x$, cerebral cortex ; $B g$, basal ganglia and amygdala; $T /$ $H$, thalamus and hypothalamus; $H p$, hippocampus; $C b$, cerebellum; $B s$, brainstem; $S c$, spinal cord; $O b$, olfactory bulb. Values are plotted as molecules per cell $\pm \operatorname{SD}(n=4)$.

$\beta$-gal activity in many regions of the brain, with intense activity occurring in the deep layers of the cerebral cortex, in cells associated with the mitral cell layer and glomerular layer of the olfactory bulb, cells of the islands of Calleja of the olfactory tubercle, throughout the colliculi, deep cerebellar nuclei, and the interpeduncular nucleus (Fig. $4 A$ ). $\beta$-Gal activity was very pronounced in the pyramidal layers of the hippocampus and granule cells of the dentate gyrus, the amygdala, and, to a lesser extent, multiple nuclei throughout the thalamus, hypothalamus, and mesencephalon, as was observed for the expression of MTIII mRNA by in situ hybridization. Activity was also detected in the dorsal cochlear nuclei, in a small number of Purkinje cells of cerebellar cortex and the ganglion cell layer of the retina (data not shown). Expression of the transgene throughout cortical regions was most intense in layers V-VI; however, a large number of X-Gal-stained cells were apparent in layer II and III, whereas layer IV of cortical areas was relatively devoid of $\beta$-gal activity and few X-Gal-stained cells were identified in layer I of the cerebral cortex throughout the brains of transgenic mice. In the pyriform cortex, $\beta$-gal-positive cells were present primarily in layer II, but some positively stained cells were apparent in layer III as well. Many cells throughout the pre- and parasubiculum were stained, while only cells in the dorsal portion of the subiculum demonstrated $\beta$-gal activity. $\beta$-Galactosidase activity within the hippocampus was primarily restricted to the CA1, CA2, and CA3 portion of the hippocampus and within the granule cell layer of the dentate gyrus (Fig. $4 B$ ). In Figure 4, $A$ and $B$, staining appears to be concentrated in the CA1 and dentate gyrus; however, in more lateral sections, substantial staining was also observed in CA2 and CA 3 neurons. We observed gradients in the number of cells expressing $\beta$-gal activity and staining intensity in pyramidal cell fields in the hippocampus and granule cell fields of the dentate gyrus. Large $\beta$-gal-positive cells were distributed throughout the hilus and smaller cells expressing $\beta$-gal were sparsely distributed within the fiber-rich portions of the hippocampus. In the amygdala, $\beta$-gal-positive cells were apparent in the lateral, basolateral, and amygdalocortical nuclei (data not shown). 

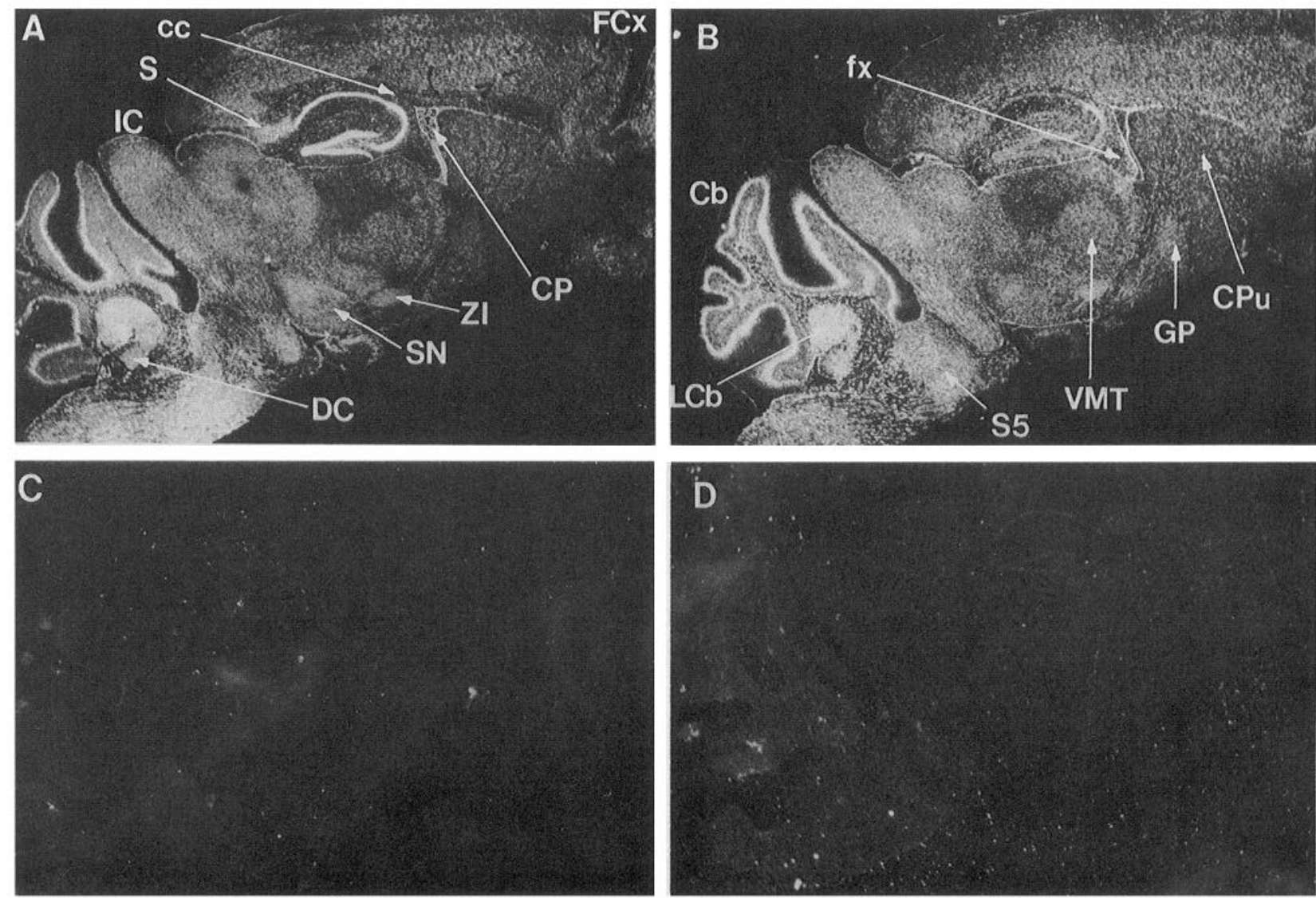

D
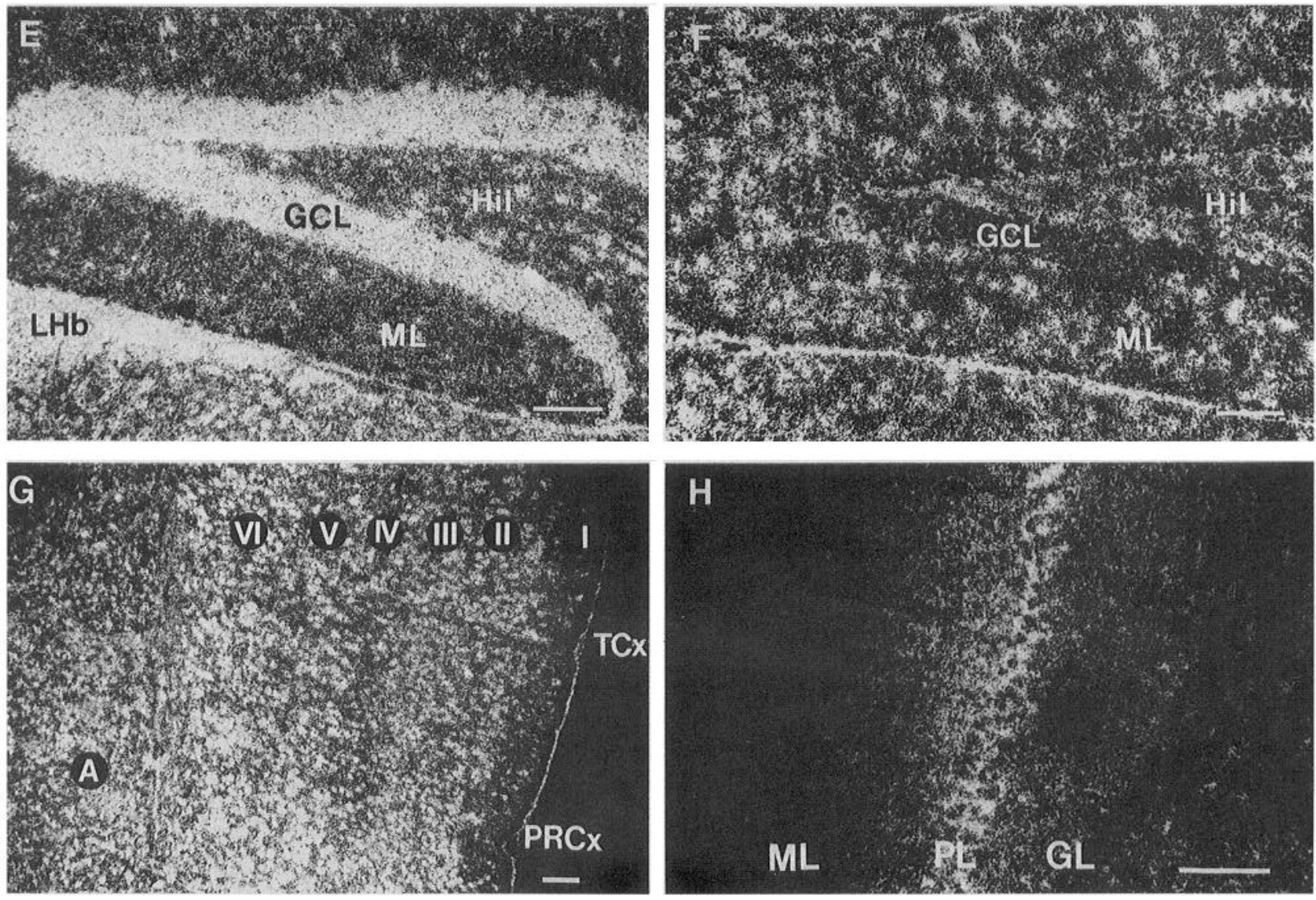

H

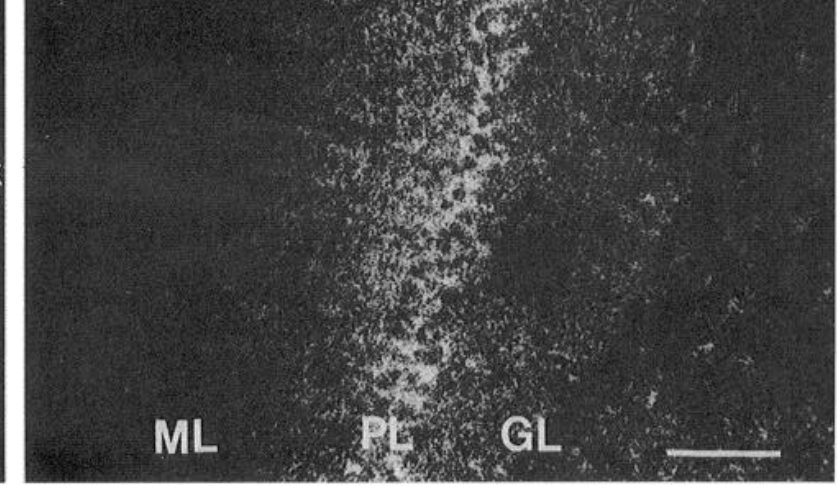


Most transgenic mouse lines showed a similar staining pattern. However, in poorly expressing lines, some brain regions did not exhibit a signal. A few discrepancies were noted between lines. Line 4708-2 exhibited greater expression in the thalamus and superior colliculus than did other lines. Line 4708-8 demonstrated robust expression in Purkinje cells within the cerebellum and the deep layers of the cerebral cortex, but had weak expression of $\beta$-gal in the hippocampus and dentate gyrus. The third established line, 4708-5, exhibited expression in the islands of Callcja (olfactory tubcrclc) and inferior colliculus (Fig. $4 A$ ), which were devoid of expression in the other transgenic lines.

Cresyl violet-stained sections from mMT-III-nlacZ transgenic mice of these same brain regions contained numerous $\beta$-gal-positive cells with neuron-like morphology (Fig. 4C). Immunohistochemical detection of neuronal and glial markers was used in conjunction with $\beta$-gal staining in several regions of the brain to confirm that neurons are the primary source of MTIII in the central nervous system. In the cortex, there was abundant costaining of cells with $\mathrm{X}-\mathrm{Gal}$ and the neuronal marker MAP-5 although not all MAP- $5^{+}$-positive cells expressed $\beta$-gal (Fig. $4 D$ ). Costaining was also observed in areas of the olfactory bulb, basal forebrain, hippocampus, cerebellum, and brainstem. Fewer than $2 \%$ of the cells that expressed the transgene marker in a representative cortical section failed to colocalize with MAP-5 immunoreactivity with the exception of ependymal cells and epithelial cells associated with the choroid plexus that were $\beta$-gal ${ }^{+}$but MAP-5- . In contrast, there was a total lack of colocalization of X-Gal-stained cells with the glial markers GFAP and $\mathrm{S} 100$ in the cortex (Fig. $4 E, F$, respectively) and elsewhere.

\section{Expression of MT-III in cultured brain cells}

Cells were isolated from neonatal MT III-nlac $Z$ transgenic mouse brains and cultured under conditions that enriched for either neurons or glia. Neuron cultures were stained by chromogenic and immunocytochemical means for the identification of $\beta$-gal activity and MAP-2, a neuronal marker. About $10 \%$ of the cells expressed both $\beta$-gal and MAP-2 (Fig. $5 A$ ), and these cells exhibited numerous neurites. No $\beta$-gal ${ }^{+} / \mathrm{MAP}-2-$ cells were observed in these cultures. No cells within the glial cultures obtained from neonatal brains stained with X-Gal after $24 \mathrm{hr}$ in culture. However, in older glial cultures ( $>1$ week in culture) small clusters of $\beta$-gal ${ }^{+}$cells $(\sim 5-10 \%$ of total cell number) were identified and approximately $50 \%$ of these X-Gal-stained cells bound antibodies directed against GFAP, suggesting that they were astrocytes (Fig. $5 B$ ). Cells that were $\beta$-gal $+/$ GFAP- exhibited similar morphologies as those cells that were $\beta$-gal ${ }^{+} / \mathrm{GFAP}^{+}$.

To ascertain whether cultured glial cells also express MT mRNA, total nucleic acids were isolated for quantitation of MT-I and MT-III mRNA by solution hybridization. Cells that had been maintained in culture for $>1$ week contained about 900 and 2100 molecules of MT-I and MT-III mRNA per cell, respectively, when grown in complete medium. MT-III expression was unaffected by the presence of phorbol 12-myristate 13acetate $(160 \mathrm{nM})$, dibutyryl cAMP $(500 \mu \mathrm{M})$, dexamethasone $(100 \mathrm{~nm})$, or $\mathrm{ZnSO}_{4}(100 \mu \mathrm{M})$ in the culture medium. Removal of serum from the medium resulted in growth arrest and differentiation as determined by morphology and GFAP induction; MT-III mRNA levels increased 2.5-fold under these conditions. In contrast to the results from primary astrocyte cultures, we could not detect MT-III mRNA in any of five transformed human astrocyte lines by solution hybridization. Quantitation of MT mRNAs in neuron cultures was not determined due to the small number of cells, and the presence of a glial feeder layer that was necessary for neuron survival.

\section{Relationship of MT-III $m R N A$ and zinc}

The histochemical localization of transition metals in the brain by sulfide precipitation (Timm, 1958) has been examined extensively (for review, see Frederickson, 1989). Although the chemical reaction is not specific for zinc, it has been shown that the same neuronal processes that stain by neo-Timm's (Danscher, 1981) also fluoresce in the presence of the zinc-specific probe TSQ (6-methoxy-8-para-toluene sulfonamide quinoline; Frederickson et al, 1992). Figure $6 A$ shows a low magnification of a sagittal section within the mouse brain stained using a neoTimm's reaction. Figure $6 C$ is a higher magnification of the hippocampus that reveals intense development of stain in giant mossy boutons of axons that arise from the granule cells of the dentate gyrus (Hjorth-Simonsen, 1973). Timm's reaction product is also abundant in axon boutons within the stratum oriens and stratum radiatum, which include projections from the CA1, CA2, and CA3 pyramidal neurons (Swanson et al., 1978; Ishizuka et al., 1990) in agreement with that observed with Timm's stain by others (Haug, 1967; Ibata and Otsuka, 1969; Crawford and Connor, 1972; Frederickson and Danscher, 1990). Figure $6 D$ shows a comparable hippocampal section showing the localization of MT-III transcripts in the granule cells of the dentate gyrus and pyramidal neurons of the CA1 to CA3. Expression of MT-III in the subiculum is heterogeneous; ventral portions appear to be devoid of MT-III expression, whereas it is abundant in dorsal regions (Fig. $6 \mathrm{D}$ ). These results are combined in the diagram (Fig. 6B), which depicts the relationship between the granule cells of the dentate gyrus and pyramidal cells of the CA1-CA3 regions as identified by in situ hybridization (light regions) and their zinc-containing axon terminals (stippled regions) identified by neo-Timm's stain within the hippocampus.

Selenide precipitation of zinc and retrograde transport of the reaction product (colchicine sensitive) has been used to identify

\footnotetext{
Figure 3. In situ hybridization of MT-III and MT-I mRNAs in brain. Sagittal sections $(10 \mu \mathrm{m})$ of adult mouse brain were hybridized with either antisense $(A, B$, and $E-H)$ or sense $(C, D)$ riboprobes corresponding to MT-III $(A, C, E, G$, and $H)$ or MT-I $(B, D$, and $F)$ mRNAs and washed as described in Materials and Methods. Hybridization to transcripts for both MT-III $(A)$ and MT-I $(B)$ were widespread throughout the brain. $C P$, choroid plexus; $C P u$, caudate-putamen; $C b$, cerebellum; $c c$, corpus callosum; $D C$, dorsal cochlear nucleus; $f x$, fornix; $F C x$, frontal cortcx; $G P$, globus pallidus; $I C$, inferior colliculus; $L C b$, lateral cerebellar nucleus; $S S$, principal sensory nucleus of V; $S N$, substantia nigra; $V M T$, ventromedial thalamic nuclei; $Z I$, zona incerta. Examination at higher magnifications $(E, G$, and $H)$ demonstrated that MT-III mRNA was evident in the granule neurons of the dentate gyrus $(E)$. $G C L$, granule cell layer of the dentate gyrus; $H i l$, hilus; $L H b$, lateral habenular nucleus; $M L$, molecular layer. In contrast MT-I transcripts in the dentate gyrus appeared to associate with cells within the glia-rich molecular layer $(F)$. MT-III expression is also associated with large, cortical neurons present primarily in the deep layers (V and VI) of the cortices and layers II and III in superficial portions $(G)$. $A$, amygdala; $P R C X$, perirhinal cortex; $T C X$, temporal cortex; $H$, urkinje cells of the cerebellum; $G L$, granule cell layer; $P L$, Purkinje cell layer; $M L$, molecular layer. Scale bar, $100 \mu \mathrm{m}$.
} 

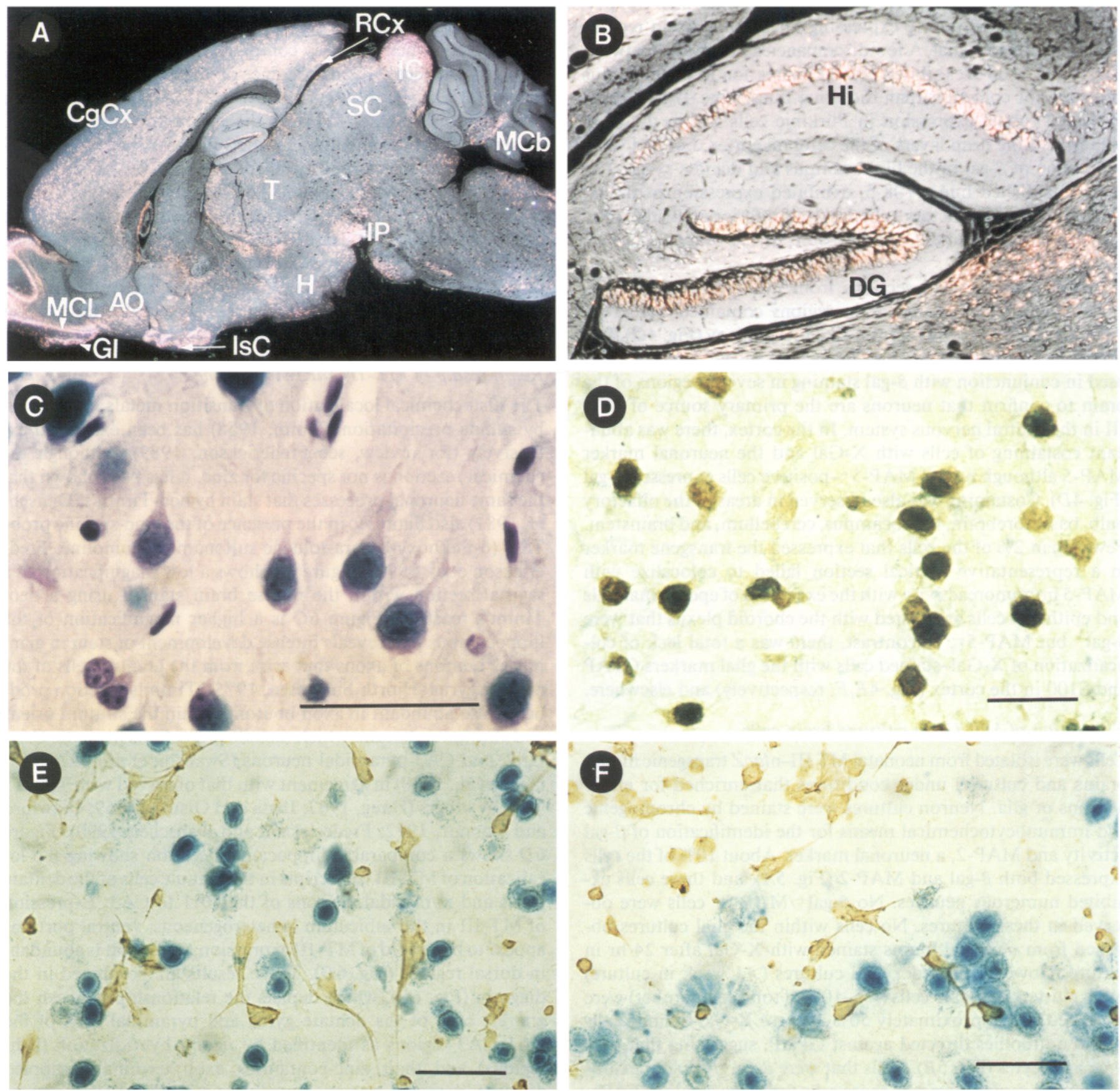

Figure 4. Expression of the mMT-III-nlacZ transgene in neurons. Adult mouse brain was isolated from animals possessing the mMT-III-nlacZ transgene and fixed in $2 \%$ paraformaldehyde, and activity of the $E$. coli $\beta$-galactosidase was detected by incubation with X-Gal chromogen at $37^{\circ} \mathrm{C}$ for 12-18 hr. $A$, Expression of the mMT III-nlacZ transgene in a medial sagittal brain section. $A O$, anterior olfactory nucleus; $C g C x$, cingulate cortex; $G l$, glomerular layer of the olfactory bulb; $I P$, interpeduncular nucleus; $I s C$, islands of Calleja; $M C b$, medial cerebellar nucleus; $M C L$, mitral cell layer; $R C x$, retrosplenial cortex; $S C$, superior colliculus; $T$, thalamus. $B$, Characteristic $\beta$-gal ${ }^{+}$pyramidal neurons were present in the hippocampus $(H i)$ and granule neurons in the dentate gyrus $(D G)$. C , Large Nissl-substance containing cells with distinct neuron-like morphologies were obvious in regions such as the colliculi. $D$, Colocalization of $\beta$-gal and the neuronal marker MAP-5 was apparent in the cortex, whereas no overlap of the glial markers GFAP $(E)$, and S100 $(F)$ were observed. Scale bar, $100 \mu \mathrm{m}$.

neurons in the CNS that possess synaptic zinc stores (Danscher, 1984; Howell and Frederickson, 1989; Slomianka et al., 1990) and a detailed localization of zinc-enriched neurons in the hippocampal region has been performed in rat (Howell et al., 1991; Slomianka, 1992; Mondava et al., 1993). When the neuronal cell bodies identified by this method are compared to the lo- cations of neurons that express MT-III mRNA and $\beta$-gal activity in the mouse brain, there is a remarkable correspondence throughout the brain as summarized in Table 1 (group I). This is particularly apparent in neocortical areas, paleocortical areas such as the pyriform cortex, presubiculum, and the hippocampus, where zinc-containing neurons and MT-III expression cor- 
Table 1. Distribution of zinc and metallothionein III expression in the CNS

\begin{tabular}{|c|c|c|c|c|c|}
\hline \multirow[b]{3}{*}{ Location } & \multicolumn{2}{|c|}{$\begin{array}{l}\text { Method of } \\
\text { zinc detection }\end{array}$} & \multirow{2}{*}{\multicolumn{2}{|c|}{ MT-III expression }} & \multirow[b]{3}{*}{ Reference } \\
\hline & \multirow{2}{*}{$\begin{array}{l}\text { Sele- } \\
\text { nite }\end{array}$} & \multirow{2}{*}{$\begin{array}{l}\text { Neo- } \\
\text { Timm's }\end{array}$} & & & \\
\hline & & & In situ & $\beta-\mathrm{gal}^{a}$ & \\
\hline \multicolumn{6}{|l|}{ Group I (colchicine sensitive) } \\
\hline Cingulate cortex, layer II & + & - & ++ & +++ & 1 \\
\hline \multicolumn{6}{|l|}{ Cerebral cortex } \\
\hline Layer II & + & ++ & ++ & ++ & 1 \\
\hline Layer III & + & + & ++ & + & 1 \\
\hline Layer V & + & +++ & +++ & +++ & 1 \\
\hline Layer VI & + & +++ & ++ & ++++ & 1 \\
\hline Pyriform cortex, layer II & + & - & n.d. & +++ & 1 \\
\hline \multicolumn{6}{|l|}{ Entorhinal cortex } \\
\hline Layer II & + & ++ & + & + & 1,2 \\
\hline Layers V-VII & + & +++ & +++ & ++ & 1,2 \\
\hline \multicolumn{6}{|l|}{ Retrosplenial cortex } \\
\hline Layer II & + & ++ & + & ++ & 2 \\
\hline Layer V & + & ++ & ++ & $++t+$ & 2 \\
\hline Presubiculum & + & ++ & n.d. & +++ & $1,2,6$ \\
\hline Hippocampus: CA1, CA2, CA3 & + & - & +++ & +++ & $1,2,3,6,7$ \\
\hline Dentate gyrus, granule cell layer & + & - & +++ & +++ & 8 \\
\hline Lateral amygdaloid nuclei & + & - & +++ & ++ & $1,3,6$ \\
\hline Amygdalohippocampal area & + & + & n.d. & $+t+$ & $1,3,6$ \\
\hline Amygdalopyriform area & + & + & n.d. & ++ & $1,3,6$ \\
\hline Islands of Calleja & + & ++ & n.d. & $++t$ & 1 \\
\hline Cochlear nucleus & + & + & ++ & +++ & 4 \\
\hline \multicolumn{6}{|l|}{ Group II (colchicine insensitive) } \\
\hline Habenular nucleus & + & + & ++ & ++ & 1 \\
\hline Zona incerta & + & + & + & ++ & 1 \\
\hline Superior colliculus & + & + & +++ & ++ & 1 \\
\hline Central gray & + & - & n.d. & + & 1 \\
\hline Reticular nucleus & + & - & n.d. & + & 1 \\
\hline Raphe nucleus & + & - & n.d. & ++ & 1 \\
\hline \multicolumn{6}{|l|}{ Others } \\
\hline Olfactory bulb & - & + & ++ & +++ & 5 \\
\hline \multicolumn{6}{|l|}{ Cerebral cortex } \\
\hline Layer I & - & ++ & - & - & 1 \\
\hline Layer IV & - & - & - & - & 1 \\
\hline Accumbens nucleus & - & ++ & n.d. & ++ & 1 \\
\hline Caudate-putamen & - & + & - & - & 1 \\
\hline Central nucleus, VMH & - & - & n.d. & + & 1 \\
\hline Subiculum & - & ++++ & $+++/-b$ & $++/-b$ & $1,6,7$ \\
\hline Substantia nigra, pars compacta & - & - & ++ & ++ & 1 \\
\hline Cerebellum & - & - & +++ & + & 1 \\
\hline
\end{tabular}

$\mp,<20 \%$ of highest expression;,$++<50 \% ;+++,<75 \% ;++++, \leq 100 \%$. n.d., no data; VMH, ventromedial hypothalamus. References are as follows: 1, Slomianka et al., 1990; 2, Slomianka, 1992; 3, Howell and Frederickson, 1989; 4, Frederickson et al., 1988; 5, Friedman and Pricc, 1984; 6, Mondava et al., 1993; 7, Howell et al., 1991; 8, Frederickson and Danscher, 1990.

a Line 4708-5.

${ }^{b}$ Basal portions of the subiculum did not express MT-III.

respond layer by layer. In addition, we have noted a gradient of mMT-III-nlac $Z$ transgene expression within the pyramidal fields of the hippocampus that appears to correspond to gradients for zinc identified by others (Howell et al., 1991; Slomianka, 1992; Mondava et al., 1993). Correspondence is also observed in the amygdala, islands of Calleja in the olfactory tubercle, and the cochlear nucleus. Thus, MT-III mRNA appears to be localized in the cell bodies of those neurons that have processes particularly rich in histochemically detectable zinc.

In addition to these colchicine-sensitive populations, selenide exposure results in silver staining of a number of colchicineinsensitive neuron populations (Table 1, group II), which are not considered to be zinc-storing neurons (Howell and Frederickson, 1989; Slomianka et al., 1990). We observed $\beta$-gal ${ }^{+}$ cells in locations identical to those that Slomianka et al. (1990) 

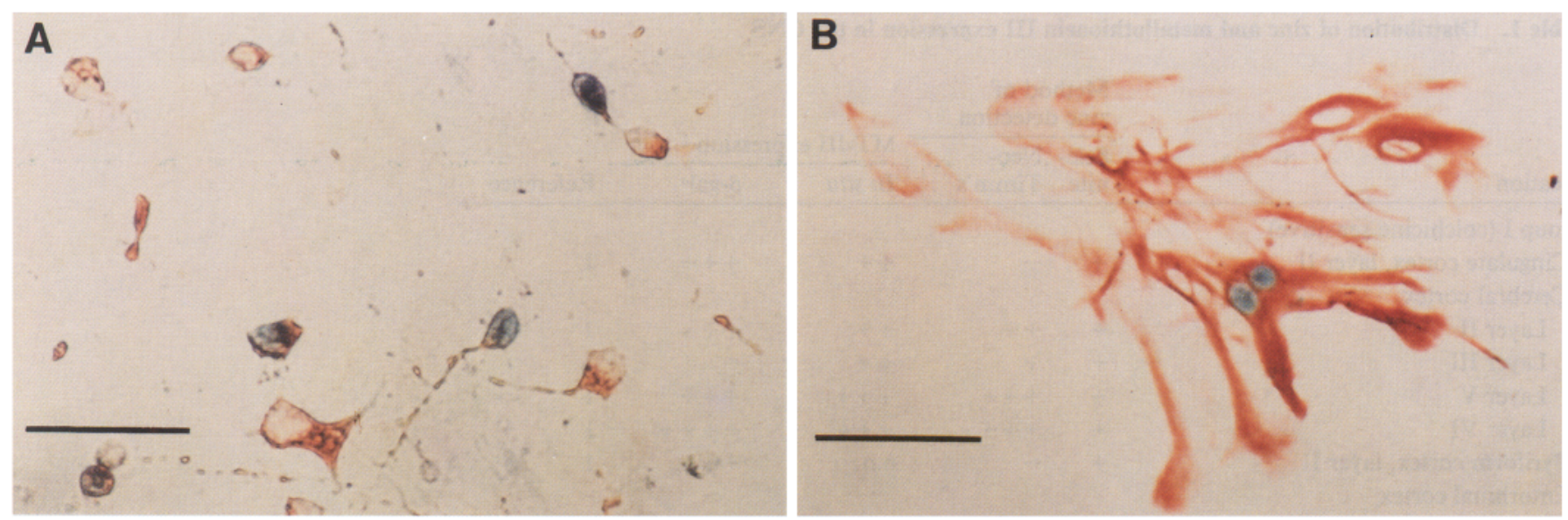

Figure 5. MT-III gene expression in both neurons and glia in vitro. Primary neuron and glial cultures were prepared from neonatal ( $<1 \mathrm{~d}$ postbirth) mouse brains and activity of the mMT-III transgene was assessed and the identity of cells in these cultures was determined with antibodies to MAP-2 or GFAP. A, Neurons isolated from 1-d-old mouse brain stained with X-Gal and antibodies that bind MAP-2. B, Glial culture from same aged brain after 1 week in culture stained with X-Gal and antibodies that bind GFAP. Scale bar, $100 \mu \mathrm{m}$.

reported containing colchicine-insensitive silver-stained neurons (Table 1). We also observed expression of MT-III mRNA and $\beta$-gal in a number of locations that do not correspond to previously identified selenite-sensitive neurons. For example, we identified $\beta$-gal expression associated with the periglomerular, mitral cell, and granule cell layers in the olfactory bulb (Fig. $4 A$ ). In Figure $6, E$ and $F$, similar sections through the olfactory bulb show Timm's sulfide precipitates and the in situ hybridization signal for MT-III mRNA, respectively, which were particularly notable over mitral cells of the bulb. Although Timm's product is apparent in these areas after sulfide perfusion (Friedman and Price 1984), the olfactory bulb is not labeled after intraperitoneal injections of selenite (Danscher, 1984; Slomianka et al., 1990) and thus it was not believed to be a site of origin of zinc-containing neuronal processes. Cells within the dorsal portion of the subiculum, the accumbens nucleus, substantia nigra, and ventromedial hypothalamus also demonstrated expression of the MT-III gene by both in situ and transgene analysis (Table 1), areas that likewise did not contain neurons of origin of zinc-containing fibers after systemic selenite administration (Howell and Frederickson, 1989; Slomianka et al., 1990). In addition to colocalization with neurons containing histochemically reactive zinc, MT-III expression was also present in epithelial cells of the choroid plexus (Fig. $6 \mathrm{H}$ ), which exhibited an intense Timm's precipitate (Fig. 6G).

\section{MT-III binds zinc and enhances its intracellular accumulation}

To assess the ability of MT-III to contribute to the Timm's stain-detectable pool of metal, a plasmid construct that allows high-level expression of mMT-III was introduced into BHK cells, which do not express MT, and a population with stable expression was selected. These cells and nontransfected BHK cells were stained by the Timm's method when subconfluent, 3 $\mathrm{d}$ after plating. Cells that expressed MT-III contained significantly more reaction product than did control cells (compare Fig. $7 A, B)$. In addition, BHK cells expressing MT-III accumulated $14.4 \pm 0.5 \mathrm{pg}$ of zinc/ng DNA versus $5.7 \pm 0.7 \mathrm{pg}$ of zinc/ng DNA in control cells, but did not exhibit alterations in the levels of 23 other metals. Addition of $5 \mu \mathrm{M}$ copper to the culture medium did not result in increased copper levels in either control or MT-III-expressing BHK cells. Furthermore, when MT-III was isolated from homogenates of cells transfected with the MT-III expression construct, zinc was the only metal detected in the fraction containing MT. These results indicate that the expression of MT-III can selectively enhance the ability of mammalian cells to sequester zinc in a histochemically reactive pool.

We attempted to determine the metal composition of MTIII in vivo by making brain homogenates from mice with inactivated MT-I and MT-II genes (Masters et al., 1994) and then purifying the MT-III by Sephadex G-75 and DEAE-Sephadex chromatography and then analyzing metal content. We detected both zinc and copper in the MT-III peak, in agreement with the results obtained by Uchida et al. (1991) for human MT-III. However, when we spiked the brain extracts with ${ }^{65} \mathrm{Zn}-$ and ${ }^{35} \mathrm{~S}$ cysteine-labeled MT-III produced in BHK cells, there was substantial $(>50 \%)$ loss of ${ }^{65} \mathrm{Zn}$ to other proteins with no loss of ${ }^{35} \mathrm{~S}-\mathrm{MT}$-III, indicating that there was exchange of metals during

Figure 6. Correlation of MT-III gene expression with areas with high zinc content. $A$, Sagittal section of mouse brain stained by neo-Timm's reaction. $A$, amygdala; $A O$, anterior olfactory nucleus; $C P u$, caudate-putamen; $D G$, dentate gyrus; $E C x$, entorhinal cortex; $F C x$, frontal cortex; $H i$, hippocampus; $O T$, olfactory tubercle; $P C x$, parietal cortex; $P a S$, parasubiculum; $P r S$, presubiculum; $S$, subiculum. In the hippocampus, distribution of histologically reactive metals $(C)$ was apparent in axonal boutons that arise from cells that express MT-III mRNA $(D)$. A composite of the in situ results (light area associated with the CA1 to CA3 and the granule cells of the dentate gyrus) and histochemical zinc (stippled areas; darker regions contain greatest zinc precipitates) with representative projections indicated in $B$. col, collaterals from the CAl of the hippocampus to the subiculum; $C A I$ and $C A 3$, pyramidal neurons of the hippocampus; $G C$, granule cell neurons; $H$, hilus; $L M L$, lacunosum molecular layer; lpp, lateral perforant pathway from the entorhinal cortex; $m f$, mossy fibers; $M L$, molecular layer of the dentate gyrus; $s c$, Schaeffer collaterals; $S O$, strata oriens; $S R$, strata radiatum. Mitral cells (arrows) in the olfactory bulb contain histologically reactive metal $(E)$ and MT-III transcripts $(F)$. $G C L$, granule cell layer; $M C L$, mitral cell layer; $E P L$, external plexiform layer. A similar colocalization of metal $(G)$ and MT-III mRNA $(H)$ also occurs in the choroid plexus $(C P) . V$, ventricle; $H b$, medial habenular nucleus. Scale bars: $C$ and $D, 200 \mu \mathrm{m} ; E-H, 50 \mu \mathrm{m}$. 

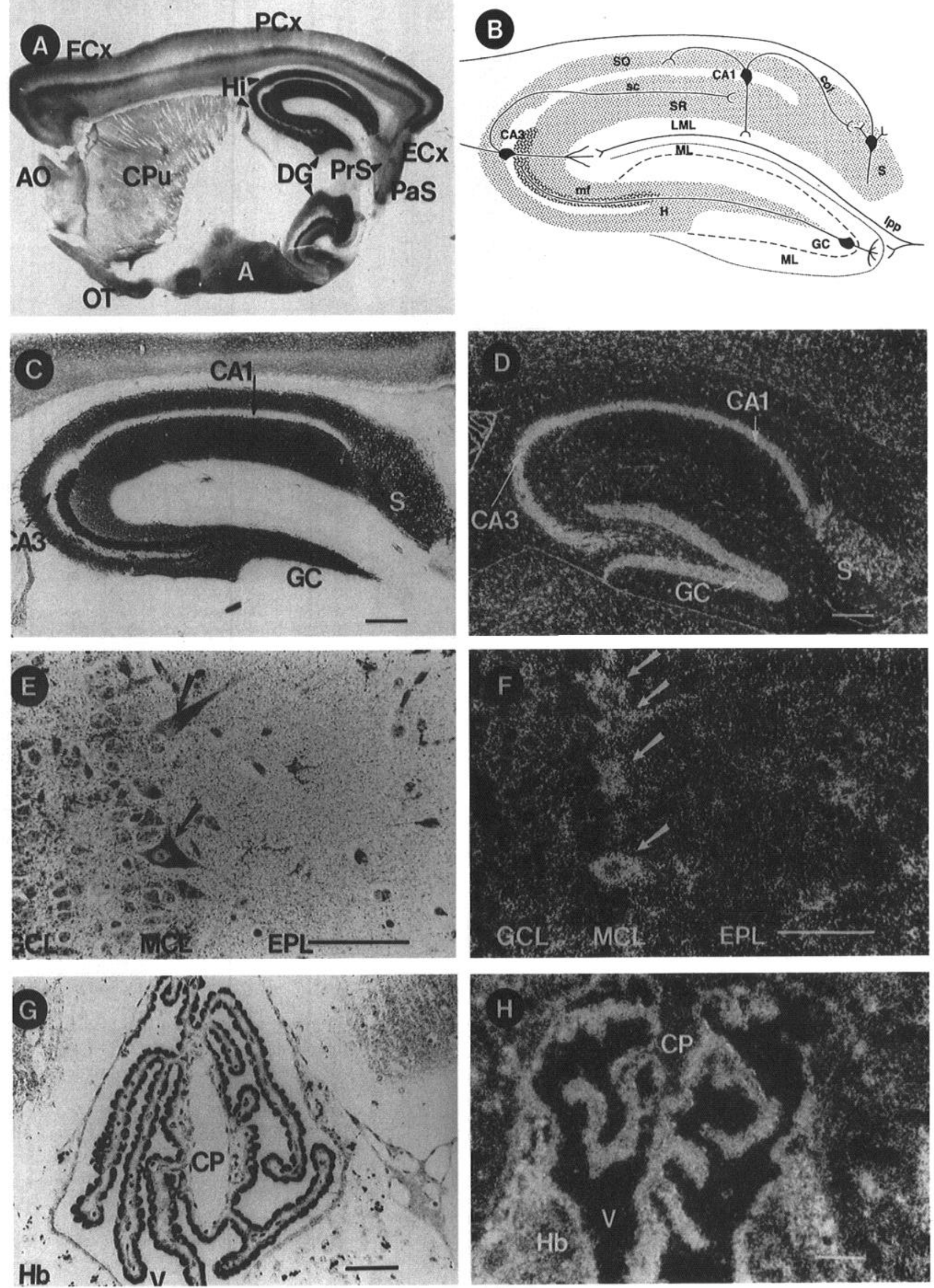

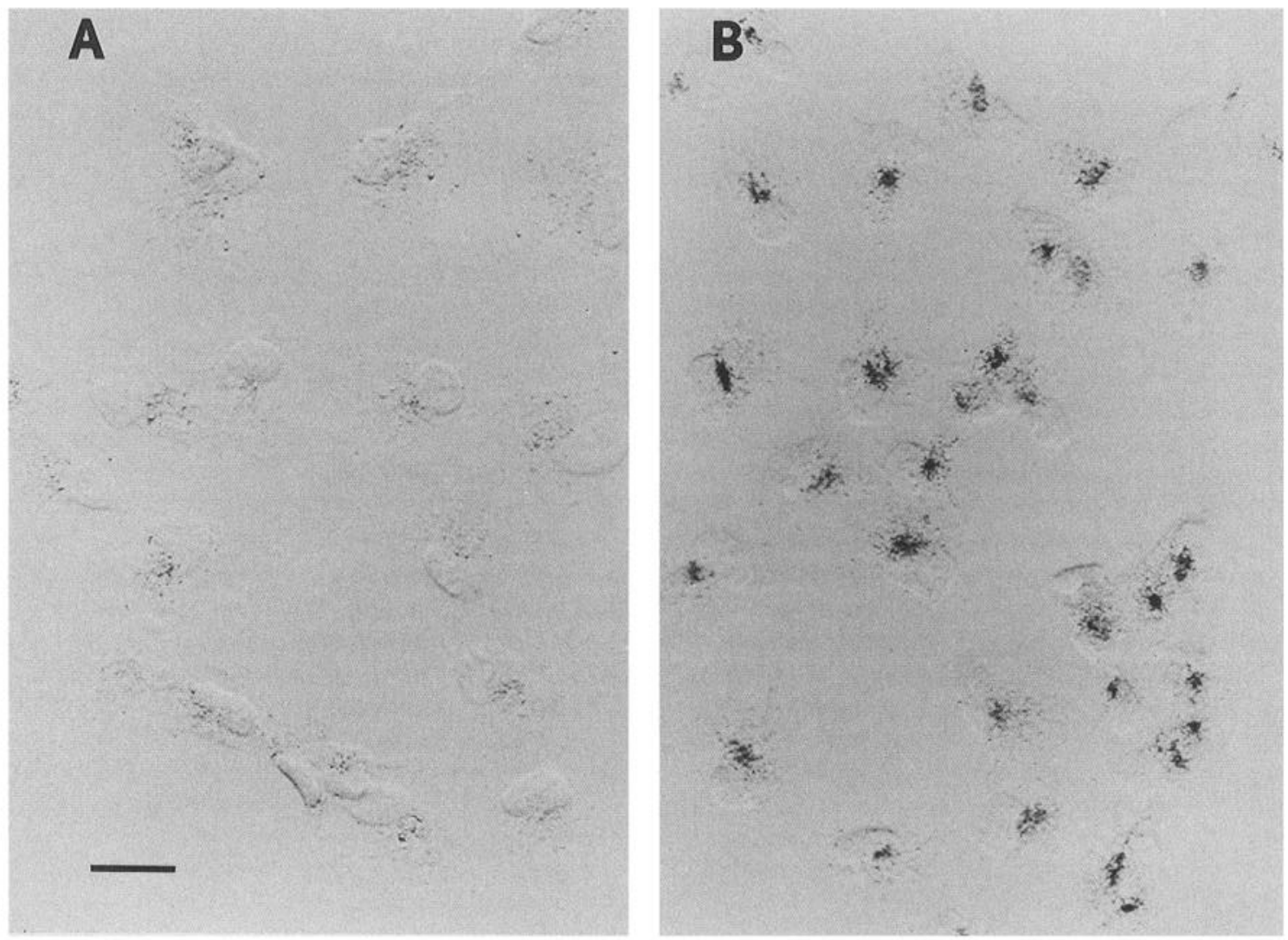

Figure 7. Accumulation of histochemically reactive zinc in BHK cells expressing MT-III. BHK cells were transfected with a pNUT-MT-III expression vector and clones were selected in the presence of $25 \mu \mathrm{M}$ cadmium. Parental $(A)$ and MT-III-expressing $(B)$ BHK cell lines were grown in DMEM, $10 \%$ FCS (containing $4 \mu \mathrm{M}$ zinc) for $3 \mathrm{~d}$ (see Materials and Methods). Histologically reactive metals were detected by a variation of the Timm's stain (Danscher, 1981). Scale bar, $25 \mu \mathrm{m}$.

purification. Because we have been unable to prevent this exchange, we cannot determine the exact metal composition of MT-III in vivo. However, the copper that is associated with MTIII purified from brain may be artifactual because copper can readily displace zinc in vitro (Winge, 1987).

\section{Discussion}

The data presented here indicate that the MT-III gene is developmentally regulated and its mRNA accumulates primarily in a subset of neurons in the mouse brain. The most intriguing aspect of MT-III mRNA distribution in the CNS is its accumulation in the cell bodies of neurons that are known to store zinc in their axon terminals. Evidence suggests that these neurons sequester zinc in synaptic vesicles and can release it upon electrical stimulation (Assaf and Chung, 1984; Howell et al., 1984). Furthermore, glutamate, GABA, and opiate receptor subtypes are responsive to physiologically relevant concentrations of zinc. Thus, zinc may be a neuromodulator; consequently, neurons containing synaptically stored zinc have been termed $\mathrm{Zn}$-ergic (Slomianka, 1992). Because MT-III binds zinc and is enriched in zinc-containing neurons, it may play a role in neuromodulation by $\mathrm{Zn}$-ergic neurons.

MT-III and MT-I mRNA accumulate in the brain with similar, but not identical, kinetics during development and are expressed concurrently in the olfactory bulb, cortex, hippocampus, brainstem, and spinal cord. Each of these mRNAs account for $\sim 0.2 \%$ of total adult brain mRNA. Differences in MT-III and
MT-I transcript distribution were particularly notable within white matter areas, but were also apparent in gray matter at higher magnifications. The expression of MT-III was largely absent in glia-rich white matter areas, while MT-I transcripts were prevalent in these areas. In addition, MT-I expression was conspicuously absent within well-defined neuron populations in the hippocampus and dentate gyrus, but abundant in fibrous portions of these structures populated by glial cell bodies. The localization of MT-I mRNA in our study agrees with that found by others using in situ hybridization (Itano et al., 1991) and immunocytochemistry (Hidalgo et al., 1991; Nishimura et al., 1992; Young et al., 1991), who concluded that MT-I is associated predominantly with glial and ependymal cells in the rat. The most obvious exception to this generalization are neurons in the CA3 portion of the hippocampus, which appear to express both MT-I and MT-III isoforms simultaneously. Although we assayed only MT-I mRNA, we assume that its abundance and distribution mimic that of MT-II mRNA as their genes are coordinately expressed and respond in parallel to various inducers (Yagle and Palmiter, 1985).

The expression of the mMT-III-nlac $Z$ transgene largely parallels the expression of endogenous MT-III transcripts. There are overlaps of expression within discrete cell populations in the hippocampus, olfactory bulb, cerebellum, thalamus, and brainstem, which suggests that many of the essential regulatory elements for appropriate expression are included in the $11.5 \mathrm{~kb}$ of the $5^{\prime}$-flanking region. However, we have noted incomplete penetrance of the mMT-III-nlac $Z$ transgene expression in cells 
shown to express MT-III mRNA and some variability of $\beta$-gal activity from one transgenic line to another. Incomplete penetrance and variability of expression have been observed with other lac $Z$ transgenes that are expressed in the nervous system (Mercer et al., 1991). These characteristics may indicate the lack of essential regulatory elements in the transgene construct, position effects exerted at the integration site, a high susceptibility to transgene inactivation, and/or differential stability of transgene mRNA or protein. Thus, the transgene results must be interpreted cautiously. They indicate what cell types and brain regions can express MT-III but may not reflect normal levels of MT-III gene expression at those sites.

The in situ hybridization data clearly revealed MT-III mRNA in some large, easily identifiable neurons but not within gliarich white matter. It was not feasible by this method to determine whether some glial cells that are interspersed with neuronal cell bodies also expressed MT-III transcripts. However, expression of the mMT-III-nlac $Z$ transgene demonstrated histochemical and immunological colocalization of $\beta$-gal activity with Nissl substance or the neuronal marker MAP-5 throughout the brain. No $\beta$-gal-positive cells were immunoreactive for the glial markers S100 and GFAP. Thus, we conclude that MT-III is expressed predominantly in neurons within the adult mouse brain. The neuronal expression of MT-III in the mouse is contrary to the conclusion reached by Uchida et al. (1991) in the neocortex of the human brain using polyclonal antisera specific for hMT-III. In histological sections, they observed a gradient of staining in the cortex, with the most intense staining in the deepest layers of the cortex, and an inverse pattern of GFAP distribution (Uchida, 1993). Nevertheless, they concluded that the MT-III-immunoreactive cells are "exclusively astrocytes" (Uchida et al., 1991). In our study, the expression of MT-III mRNA and the mMT III-nlac $Z$ transgene were likewise greatest in the deeper layers in the cortex, but were associated with cells with neuron-like morphology that were MAP-5 immunoreactive. Cells expressing MT-III could be different in mouse and human or MT-III may be synthesized in neurons, but it may accumulate in, or is in close association with, glial cells. We have been unable to produce antisera to either the same peptide uscd by Uchida et al. (1991) or a maltose-binding protein-MTIII fusion protein despite repeated attempts. Thus, we were not able to reconcile these disparate results.

Although we have no evidence for MT-III expression in glial cells in vivo, when astrocytes were cultured, some of them became $\beta$-gal positive after a week in culture. Furthermore, these cultures expressed high levels of MT-I and MT-III mRNA, much higher than the levels found in total mouse brain. Thus, some aspect of the culture conditions can induce MT-III expression. These observations suggest that MT-III might be induced in glial cells in vivo under some conditions.

Endogenous vesicular zinc is prominent within the structures of the hippocampus, where it is sequestered primarily in mossy fiber terminals of granule neurons that have their cell bodies in the dentate gyrus and in the collateral nerve fibers (van Groen and Wyss, 1990) from the CA1 and CA3 pyramidal neurons (Haug, 1967; Ibata and Otsuka, 1969; Crawford and Conner, 1972; Fredickson and Dancher, 1990). These cell bodies give the most intense hybridization signal for MT-III mRNA, thus suggesting a relationship between MT-III expression and zinc storage (Fig. 6B). Neuronal cell bodies in rat that give rise to synaptic terminals containing zinc have been identified by retrograde transport and detection of zinc-selenite precipitates
(Danscher, 1984; Howcll and Frcdcrickson, 1989; Slomianka et al., 1990; Slomianka, 1992). The results of these studies are summarized in Table 1 along with our localization of MT-III mRNA and mMT-III-nlacZ expression. There is a remarkably good correlation among these observations, such that anatomical locations of $\mathrm{Zn}$-ergic cell bodies and the relative intensity of selenide-staining coincide with locations and level of MT-III expression. In a few regions, such as the olfactory bulb and cerebellum, we observed MT-III and transgene expression in neurons that are not believed to be $\mathrm{Zn}$-ergic. We have observed reproducible neo-Timm's histochemical stain in olfactory bulb; however, we failed to observe a significant Timm's reaction in cerebellum. The labeling intensity of neuron cell bodies identified by selenide-zinc precipitates is proportional to the amount of zinc present within their terminals and is influenced by the dilution of selenite from the site of administration. Thus, some neurons may fail to be labeled or identified by the selenideprecipitate method. Alternatively, MT-III expression may not be limited to just those neurons that store zinc within their synaptic boutons. It may regulate other metals, such as copper, in neurons that require these metals in their specialized functions. Zinc is the most abundant transition metal in the brain after iron (Goody et al., 1975; Chan et al., 1984) and it is found in three pools: free or loosely associated (Kawaguchi et al., 1987), bound to metalloproteins (Vallee and Falchuk, 1993), and in vesicles that are concentrated in synaptic terminals (Ibata and Otsuka, 1969; Friedman and Price, 1984; Pérez-Clausell and Danscher, 1985). Although Timm's reaction can detect a variety of metals, a body of evidence suggests that synaptically stored zinc is responsible for most of the staining in the brain by this method (Danscher et al., 1985; Frederickson et al., 1992). The expression of MT-III in neurons that sequester zinc in synaptic vesicles within their terminals prompts us to speculate that MTIII may play some role in the storage of zinc in these neurons. We have begun to substantiate this possibility by determining that zinc is bound to MT-III in vivo and by showing that transfected cells expressing MT-III accumulate zinc and produce a more intense reaction with Timm's stain. The increased intensity of Timm's precipitates seen in BHK cells in response to MT-III expression appears to be greater than the 2.5 -fold increase of zinc concentration measured in these same cells suggesting that sulfide only reacts with a fraction of intracellular zinc and that MT-III contributes to that fraction.

Zinc possesses characteristics of a neuromodulator for the ionotropic glutamate receptors (Peters et al., 1987; Westbrook and Mayer, 1987) and is released at glutamatergic synapses in response to depolarization (Assaf and Chung, 1984; Howell et al., 1984). The response to zinc is dependent on the receptor subtype. It inhibits activity of the NMDA receptor-associated ion channels (Peters et al., 1987; Westbrook and Mayer, 1987; Mayer et al., 1989; Christine and Choi, 1990; Rassendren et al., 1990), but potentiates the activity of amino-3-hydroxy-5-methylisoxazol-4-propionic acid (AMPA) and kainic acid (KA) receptors at low concentrations and inhibits them at concentrations greater than $100 \mu \mathrm{M}$ (Mayer et al., 1989; Rassendren et al., 1990). In addition, zinc also binds to $\mathrm{GABA}_{\mathrm{A}}$ receptors (Smart, 1992) and blocks GABA-gated ion currents at these receptors (Westbrook and Mayer, 1987; Mayer and Vyklicky, 1989; Draguhn et al., 1990; Xie and Smart, 1991). Many of the neurons that express MT-III, such as pyramidal cells of the hippocampus and granule neurons of the dentate gyrus, utilize glutamate (Crawford and Conner, 1973; Taxt and Storm-Math- 
isen, 1984; Terrian et al., 1988; Bramham et al., 1990), while others, such as Purkinje cells, utilize GABA (Fonnum et al., 1970; Fonnum and Walberg, 1973) as their primary neurotransmitters. Thus, such neurons may store and/or release zinc along with glutamate or GABA at their synapses and this released zinc may serve to modulate the activity of these neurotransmitters. Zinc has also been demonstrated to act as an endogenous ligand for the $\sigma 2$ opioid receptor in rat brain (Conner and Chavkin, 1992).

Several potential functions for MT-III in Zn-ergic neurons can be envisioned. MT-III may play a role in the uptake of zinc into neurons, or storage or transport of zinc within neurons and/ or synaptic vesicles. Alternatively, it may protect these neurons from metal toxicity or oxygen radical damage. MT-I and -II, in contrast, which appear to be expressed predominantly in glial cells, may serve primarily to assist in the sequestration of zinc that is liberated from Zn-ergic neurons. Clearly, other approaches will be necessary to establish a more defined relationship between MT-III and synaptic zinc and to elucidate the functions of MT-III in these neurons. However, the results presented here provide a framework for investigating the role of MT-III in neurophysiology.

\section{References}

Assaf S, Chung S (1984) Release of endogenous $\mathrm{Zn}^{2+}$ from brain tissue during activity. Nature 308:734-738.

Basu A, Lazo JS (1990) A hypothesis regarding the protective role of metallothioneins against the toxicity of DNA interactive cancer drugs. Toxicol Lett 50:123-135.

Beach LR, Palmiter RD (1981) Amplification of the metallothionein-I gene in cadmium-resistant mouse cells. Proc Natl Acad Sci USA 78: 2110-2114.

Bramham CR, Torp R, Zhang N, Storm-Mathisen J, Ottersen OP (1990) Distribution of glutamate-like immunoreactivity in excitatory hippocampal pathways: a semiquantitative electron microscopic study in rats. Neuroscience 39:405-417.

Bremner I (1991) Nutritional and physiologic significance of metallothionein. Methods Enzymol 205:25-35.

Brinster RL, Chen H, Trumbauer M, Yagle MK, Palmiter RD (1985) Factors affecting the efficiency of introducing foreign DNA into mice by microinjecting eggs. Proc Natl Acad Sci USA 82:4438-4442.

Chan AWK, Minski MJ, Lai JCK (1984) An application of neutron activation analysis to small biological samples: simultaneous determination of thirty elements in the rat brain. $J$ Neurosci Methods 7:317-318

Choudhuri S, McKim JM Jr, Klaassen CD (1993) Differential expression of the metallothionein gene in liver and brain of mice and rats. Toxicol Appl Pharmacol 1 19:1-10.

Christine CW, Choi DW (1990) Effect of zinc on NMDA receptormediated channel currents in cortical neurons. J Neurosci 10:108116.

Connor MA, Chavkin C (1992) Ionic zinc may function as an endogenous ligand for the haloperidol-sensitive sigma 2 receptor in rat brain. Mol Pharmacol 42:471-479.

Crawford IL, Conner JD (1972) Zinc in maturing rat brain: hippocampal concentration and localization. Neurochemistry 19:1451-1458.

Crawford IL, Conner JD (1973) Localization and release of glutamic acid in relation to the hippocampal mossy fibre pathway. Nature 244 $442-443$.

Danscher G (1981) Histochemical demonstration of heavy metals. A revised version of the sulphide silver method suitable for both light and electron microscopy. Histochemistry 71:1-16.

Danscher G (1984) Do the Timm silver-sulphide and the selenium method demonstrate zinc in the brain? In: The neurobiology of zinc, Vol 2 (Frederickson CJ, Howell GA, Kasarkis EJ, eds), pp 273-288. New York: Liss.

Danscher G, Howell G, Pérez-Clausell J, Hertel N (1985) The dithiozine, Timm's sulphide silver and the selenium methods demonstrate a chelatable pool of zinc in the CNS. Histochemistry 83:419-422.
Draguhn A, Verdorn TA, Ewert M, Seeburg PH, Sakman B (1990) Functional and molecular distinction between recombinant rat GA$\mathrm{BA}^{\mathrm{A}}$ receptor subtypes by $\mathrm{Zn}^{+}$. Neuron 5:781-788.

Durnam DM, Palmiter RD (1987) Analysis of the detoxification of heavy metals by mouse metallothionein. Experientia [Suppl] 52:457463.

Ebadi M (1991) Metallothioneins and other zinc-binding proteins in the brain. Methods Enzymol 205:363-387.

Fassel VA (1978) Quantitative elemental analysis by plasma emission spectroscopy. Science 202:183-191.

Fonnum F, Walberg F (1973) An estimate of the concentration of $\gamma$-aminobutyric acid and glutamate decarboxylase in inhibitory Purkinje axon terminals in the cat. Brain Res 54:115-127.

Fonnum F, Storm-Mathisen J, Walberg F (1970) Glutamate decarboxylase in inhibitory neurons: a study of the enzyme in Purkinje cell axons and boutons in the cat. Brain Res 20:259-275.

Frederickson CJ (1989) Neurobiology of zinc and zinc-containing neurons. Int Rev Neurobiol 31:145-238.

Frederickson CJ, Danscher G (1990) Zinc-containing neurons in hippocampus and related CNS structures. Prog Brain Res 83:71-84.

Frederickson CJ, Howell GA, Haigh MD, Danscher G (1988) Zinccontaining fiber systems in the cochlear nuclei of the rat and mouse. Hear Res 36:203-211.

Frederickson CJ, Rampy BA, Reamy-Rampy S, Howell GA (1992) Distribution of histochemically reactive zinc in the forebrain of the rat. J Chem Neuroanat 5:521-530.

Friedman B, Price JL (1984) Fiber systems in the olfactory bulb and cortex: a study in adult and developing rats, using the Timm method with the light and electron microscopes. J Comp Neurol 223:88-109.

Goody W, Hamilton EI, Williams TR (1975) Spark-source mass spectrometry in the investigation of neurological disease. II. Element levels in brain, cerebrospinal fluid and blood: some observations on their abundance and significance. Brain 98:65-70.

Hamer DH (1986) Metallothionein. Annu Rev Biochem 55:913-951.

Hart BA, Voss GW, Shatos MA, Doherty J (1990) Cross tolerance to hyperoxia following cadmium aerosol pretreatment. Toxicol Appl Pharmacol 103:255-270.

Haug FMS (1967) Electron microscopical localization of zinc in the mossy fibre synapse by a modified sulfide-silver procedure. Histochemie 8:355-368.

Hidalgo J, Campmany L, Marti O, Armario A (1991) Metallothionein-I induction by stress in specific brain areas. Neurochem Res 16:11451148.

Hidalgo J, García A, Oliva AM, Giralt M, Gasull T, González B, Milnerowicz $\mathrm{H}$, Wood A, Bremner I (1994) Effect of zinc, copper and glucocorticoids on metallothionein levels of cultured neurons and astrocytes from rat brain. Chem-Biol Interact, in press.

Hjorth-Simonsen A (1973) Some intrinsic connections of the hippocampus in the rat: an experimental analysis. J Comp Neurol 147: 145-162.

Howell GA, Frederickson CJ (1989) A retrograde transport method for mapping zinc-containing fiber systems in the brain. Brain Res 515:277-286.

Howell GA, Welch MG, Frederickson CJ (1984) Stimulation-induced uptake and release of zinc in hippocampal slices. Nature 308:736738.

Howcll GA, Pćrcz-Clauscll J, Frcdcrickson CJ (1991) Zinc containing projections to the bed nucleus of the stria terminalis. Brain Res 562: $181-189$.

Ibata Y, Otsuka N (1969) Electron microscopic demonstration of zinc in the hippocampal formation using Timm's sulfide-silver technique. J Histochem Cytochem 17:171-175.

Ishizuka N, Weber J, Amaral DG (1990) Organization of intrahippocampal projections originating from $\mathrm{CA} 3$ pyramidal cells in the rat. J Comp Neurol 295:580-623.

Itano Y, Noji S, Koyama S, Taga N, Takahashi T, Ono K, Kosaka F (1991) Bacterial endotoxin-induced expression of metallothionein genes in rat brain, as revealed by in situ hybridization. Neurosci Lett 124:13-16.

Kägi JHR, Kojima Y (1987) Chemistry and biochemistry of metallothionein. Experientia [Suppl] 52:25-63.

Kawaguchi Y, Katsumaru H, Kosaka T, Heizmann CW, Hama K (1987) Fast spiking cells in rat hippocampus (CAl region) contain the calcium-binding protein parvalbumin. Brain Res 416:369-374.

Marks DL, Wiemann JN, Burton KA, Lent KL, Clifton DK, Steiner 
RA (1992) Simultaneous visualization of two cellular mRNA species in individual neurons by the use of a new double in situ hybridization method. Mol Cell Neurosci 3:395-401.

Masters BA, Kelly EJ, Quaife CJ, Brinster RL, Palmiter RD (1994) Targeted disruption of metallothionein-I and -II genes increases sensitivity to cadmium. Proc Natl Acad Sci USA 91:584-588.

Mayer ML, Vyklicky I, Jr (1989) The action of zinc on synaptic transmission and neural excitability in cultures of mouse hippocampus. $\mathbf{J}$ Physiol (Lond) 415:351-365.

Mayer ML, Vyklicky L Jr, Westbrook GL (1989) Modulation of excitatory amino acid receptors by group IIb metal cations in cultured mouse hippocampal neurones. J Physiol (Lond) 415:329-350.

Mercer EH, Hoyle GW, Kapur RP, Brinster, RL, Palmiter RD (1991) The dopamine-hydroxylase gene promoter directs expression of $E$. coli lac $Z$ to sympathetic and other neurons in adult transgenic mice. Neuron 7:703-716.

Mondava P, Howell GA, Frederickson CJ (1993) Zinc-containing neuronal innervation to the septal nucleus. Brain Res 608:115-122.

Nishimura N, Nishimura H, Ghaffer A, Tohyama C (1992) Localization of metallothionein in the brain of rat and mouse. J Histochem Cytochem 40:309-315.

Palmiter RD (1987) Molecular biology of metallothionein gene expression. Experientia [Suppl] 52:63-80.

Palmiter RD, Chen HY, Brinster RL (1981) Differential regulation of metallothionein-thymidine kinase fusion genes in transgenic mice and their offspring. Cell 29:701-710.

Palmiter RD, Behringer RR, Quaife CJ, Maxwell F, Maxwell IH, Brinster RL (1987) Cell lineage ablation in transgenic mice by cell-specific expression of a toxin gene. Cell 50:435-443.

Palmiter RD, Findley SD, Whitmore TE, Durnam DM (1992) MTIII, a brain-specific member of the metallothionein gene family. Proc Natl Acad Sci USA 89:6333-6337.

Pérez-Clausell J, Danscher G (1985) Intravesicular localization of zinc in rat telencephalic boutons. A histochemical study. Brain Res 337: 91-98.

Peters S, Koh J, Choi DW (1987) Zinc selectively blocks the action of $N$-methyl-D-aspartate on cortical neurons. Science 236:589-592.

Rassendren FA, Lory P, Pin JP, Nargeot J (1990) Zinc has opposite effects on NMDA and non-NMDA receptors expressed in Xenopus oocytes. Neuron 4:733-740.

Slomianka L (1992) Neurons of origin of zinc-containing pathways and distribution of zinc-containing boutons in the hippocampal region of the rat. Neuroscience 48:325-352.

Slomianka L, Danscher G, Frederickson CJ (1990) Labeling of the neurons of origin of zinc-containing pathways by intraperitoneal injections of sodium selenite. Neuroscience 38:843-854.

Smart TG (1992) A novel modulatory binding site for zinc on the GABA receptor complex in cultured rat neurones. J Physiol (Lond) 447:587-625.

Suzuki KT, Imura N, Kimura M (1993) Metallothionein III: biological role and medical implications. Basel: Birkhäuser.
Swanson LW, Wyss JM, Cowen WM (1978) An autoradiographic study of the organization of intrahippocampal association pathways in the rat. J Comp Neurol 181:681-716.

Tamai KT, Gralla EB, Ellerby LM, Valentine JS, Thiele DJ (1993) Yeast and mammalian metallothioneins functionally substitute for yeast copper-zinc superoxide dismutase. Proc Natl Acad Sci USA 90: 8013-8017.

Taxt T, Storm-Mathisen J (1984) Uptake of D-aspartate and L-glutamate in excitatory axon terminals in hippocampus: autoradiographic and biochemical comparison with $\gamma$-aminobutyrate and other amino acids in normal rats and rats with lesions. Neuroscience 11:79100.

Terrian DM, Johnston D, Claiborne BJ, Ansah-Yiadom R, Strittmatter WJ, Rea MA (1988) Glutamate and dynorphin release from a subcellular fraction enriched in hippocampal mossy fiber synaptosomes. Brain Res Bull 21:343-351.

Thornalley PJ, Vasak M (1985) Possible role for metallothionein in protection against radiation-induced oxidative stress. Kinetics and mechanism of its reaction with superoxide and hydroxyl radicals. Biochim Biophys Acta 827:36-44.

Timm F (1958) Zur histochemie der Schwermetalle. Das Sulfid-SilberVerfahren. Dtsch Z ges gericht Med 46:706-711.

Uchida Y (1993) Growth inhibitory factor in brain. In: Metallothionein III: biological role and medical implications (Suzuki KT, Imura N, Kimura M, eds), pp 315-328. Basel: Birkhäuser.

Uchida Y, Takio K, Titani K, Ihara Y, Tomonaga M (1991) The growth inhibitory factor that is deficient in the Alzheimer's disease brain is a 68 amino acid metallothionein-like protein. Neuron 7:337347.

Vallee BL, Falchuk KH (1993) The biochemical basis of zinc physiology. Physiol Rev 73:79-117.

van Groen T, Wyss JM (1990) The postsubicular cortex of the rat: characterization of the fourth region of the subicular cortex and its connections. Brain Res 529:165-177.

Webb M (1979) Functions of hepatic and renal metallothionein in the control of the metabolism of cadmium and certain other bivalent cations. Experientia [Suppl] 43:313-319.

Westbrook GL, Mayer ML (1987) Micromolar concentrations of $\mathrm{Zn}^{++}$ antagonize NMDA and GABA responses in hippocampal neurones. Nature 328:640-643.

Winge DR (1987) Copper coordination in metallothionein. Experientia [Suppl] 52:213-218.

Yagle MK, Palmiter RD (1985) Coordinate regulation of mouse metallothionein I and II genes by heavy metals and glucocorticoids. Mol Cell Biol 5:291-294.

Young JK, Garvey JS, Huang PC (1991) Glial immunoreactivity for metallothionein in rat brain. Glia 4:602-610.

Xie XM, Smart TG (1991) A physiological role for endogenous zinc in rat hippocampal synaptic transmission. Nature 349:521-524. 